\title{
6 Muslim Religious Narratives and Perceptions of Christianity
}

As for the Christians... The Christians, well, please don't be offended but they are deluded. They are deluded to believe in the cross, and in azreti Isa. Azreti was created, Miriam is his mother.

(Interview 3, Ribnovo 2005)

One simile in particular came up repeatedly in my field research, namely the idea that the difference between Islam and Christianity was very small, "as thin as an onion skin”. Initially, I presumed this was an off-the-cuff metaphor, coined in reply to my ethnographic querying, but the simile seems to be more established. One female respondent, Shukri of Gorno Drianovo, attributed it all the way back to the prophet Muhammad:

M.L.: What are the differences between the Bible and the Qur'an?

S.: The difference? Let me give you an example from the times of Muhammad. When he began to spread Islam and the idolaters expelled him from Mecca to Medina, Christians welcomed him in Medina. They asked him, why did you get expelled by the idolaters, what kind of religion are you preaching? He began to answer them. And they said, the difference between Christianity and Islam is like an onion skin. It's so small. So, there aren't any important differences. (M, M, Interview 38, Leshten 2006)

Fanny J. Blunt ${ }^{334}$ recorded the same metaphor in a sermon given by a 19th-century hodzha ${ }^{335}$ who told his congregation, "O true believers, open your purses every one of you, and give largely to the poor and needy! Refuse no charity either to Muhammadans or Christians, for they are separated from us only by the thickness of the skin of an onion" (Blunt 2005 [oryg. 1878], p. 160). The metaphor was presumably an established foundational element of local $^{336}$ religious tolerance aimed at bringing the two religious groups together and defusing their potentially destabilizing differences. The image of an object as small and insignificant as an onion skin ${ }^{337}$ neutralizes the fear of religious conflict. Why fight over an onion skin, the metaphor implies, if the

334 A British consul's daughter married to another consul, Blunt spent twenty years living in European and Asian parts of Turkey in the second half of the 19th century.

335 F.J. Blunt does not identify the location but the context suggests the semon was preached in Dobrudzha.

336 As a matter of conjecture, the metaphor may plausibly be known in other religiously mixed communities in the former Ottoman territories, possibly even quite far-flung ones. This is suggested not only by the 19th-century accounts of Fanny J. Blunt but also by a similar account recorded M. Lubaś in Western Macedonia, a fair distance from my research location (Lubaś 2011, p. 228).

337 Christians use the same simile.

(cc) BY-NC-ND $(C) 2015$ Magdalena Lubanska

This work is licensed under the Creative Commons Attribution-NonCommercial-NoDerivs 3.0 License. 
core of the Abrahamic tradition is shared by Muslims, Jews and Christians alike, even though it is obscured by a thin layer of outward practices. Each of the religions considers itself to be the true heir of the tradition (and its competitors to be usurpers) to create "symbolic boundaries" which "are necessary even for the private organizing of experience. But public rituals which perform this function are also necessary to the organizing of society" (Douglas 2003, p. 53).

According to Florentina Badalanova, the oral tradition in the Balkans can be seen as "an implicit bridge between different confessional patterns and as a verbal paradigm of popular faith” (Badalanova 2001, p. 37), which Badalanova believes to be an alternative to the canonical and apocryphal texts of the Old and New Testament and of the Qur'an (Badalanova 2001, p. 52), suggesting a history of hidden cross-pollination between the Jewish, Christian and Jewish-Muslim oral variants (cf. Badalanova 2001, p. 37; Badalanova 2002a, p. 63). The influence of Judaism and Christianity on Islam can also be found outside of the Balkans, going back to Islam's formative period in the Arabian Peninsula where, as Marek Starowieyski ${ }^{338}$ speculates, the Ebionite variant of JudaeoChristian theology probably played a major role in the process (Starowieyski 2003a, p. 246). According to Galina Lozanova ${ }^{339}$, narratives and stories of biblical origin must have infiltrated early Islam through the influence of Christians and Jews converted to Islam in its early centuries, mainly through oral transmission. Such narratives featured "Old Testament prophets and wise men, Jesus Christ and the Apostles, martyrs and monks. At first the stories were spread by Jews and Christians, and later also by itinerant folk singers ${ }^{340}$ " (Lozanova 2008, p. 15, my translation). The connections with the Jewish and Christian traditions are also apparent in some religious Islamic writings, such as al-Tabari's ${ }^{341}$ Tarikh al-Rusul wa-al-Muluk (A History of Prophets and Kings, known as The History of al-Tabari ${ }^{342}$ ) or al-Tha'labi's Lives of the Prophets.

338 Marek Starowieyski is a Catholic priest and a well-known Polish theologian and patristic scholar, editor of Poland's best-known multi-volume edition of Christian apocrypha.

339 Galina Lozanova is a folklorist and researcher from the Bulgarian Academy of Sciences specializing in the Muslim oral narrative tradition in Bulgaria.

340 In Arabic: qisasi (storyteller).

341 Al-Tabari (838-923), an Arab historiographer and theologian of Persian descent, author of many books of commentary on the Qur'an collectively known as Tafsir al-Tabari and History of the Prophets and Kings (Tarikh al-Rusul wa-al-Muluk), also known as The History of al-Tabari. This monumental history of the world from its beginning until 915 is a remarkable achievement for a single scholar. For al-Tabari, the different strands in his writing formed a coherent whole since the Arabic Muslim culture of the day did not make a clear-cut distinction between Islam and historiography. Al-Tabari does not engage polemically with his historical material (creation of the world, the prophets, ancient Arab history), and often uses the hadith structure to communicate information about historical or religious events (Bielawski 1995, p. 175-176).

342 This historical and religious story has a hadith-like structure in that it contains a chain of narration or isnad and the text proper ( $\mathrm{matn}$ ), and the author relies on texts from isra'iliyyat, a body of narratives originating from the Jewish and Christian tradition. 
Ultimately, the chronology and origins of the metaphor remain a matter of conjecture: was it coined by Muhammad, or perhaps by Ottoman hodzhas, to serve as an instrument in the Empire's policy of peaceful religious coexistence? And if so, which faction coined it - was it first proposed by a religious writer and adopted locally, or was it invented by a local hodzha and gained wider currency? The metaphor was noted in the field by myself and by Fanny J. Blunt writing 200 years ago - a coincidence or a case of cultural longue durée?

We cannot be certain, but as ethnographers we may look for answers to different questions - how does this metaphor (mostly used by Muslims) relate to other aspects of the daily coexistence of Muslims and Orthodox Christians in the Western Rhodopes?

Taken literally, the metaphor seems to imply that the two religions are united by a single canon, their differences being very much a matter of secondary importance. This is a false impression, as my respondents make clear in more in-depth conversations. Like the protestations of brotherly love between Muslims and Christians discussed in the earlier chapters, the metaphor is another way of upholding good relations between neighbours who are members of different religious groups.

The metaphor contains a positive message of religious tolerance between religious groups, which is underpinned by a desire to protect group boundaries and by a mistrust of the (still sporadic) mixed marriages, as suggested by another local proverb, "Every frog knows which puddle it belongs in". The narratives below have been chosen to illustrate what Muslims tend to make of the Christian "puddle", and why they are not too eager to join them in the same puddle.

Muslims in the Rhodopes must relate to Jews and Christians as members of the youngest monotheistic religion and inhabitants of a religiously mixed area. Their narratives about Christians and Christianity tend to vary depending on the model of Islam they embrace (Adat or Salafi) and the personal level of competence in matters of religion. Those less knowledgeable have no understanding of circumcision or baptism, other than the fact that the two practices mark the religious identity of members of a given group.

More competent respondents, particularly those who embrace "Adat Islam", primarily emphasize the religious boundaries between Islam and Christianity by presenting Christianity as a religion based on human error, distorting revealed religion. In doing so they invoke events from sacred narratives which function as norms or models for interpreting reality. One important element in such narratives involves demonstrating Islam's superiority to Christianity, which for Adat Muslims mainly applies to the symbolic sphere. By way of contrast, adherents of the Salafi model invoke the classic seventh-century Islam as the ideal model.

The contrast between Islam seen as the religion of salvation and Christianity seen as a religion based on a corrupted misunderstanding of revealed truth seems particularly important to Bulgarian-speaking Muslims, who feel the need to validate their religion in the eyes of Christians. The Muslims realize that their Christian neighbours consider 
them to be converts and flawed Muslims, which often boosts their levels of religious committment relative to their Christian neighbours, who by and large embrace their religion unthinkingly. Unlike the local Christians, who consider their religion to be an element of tradition and think little about its doctrines, Muslims tend to take more interest in the study of Islam. As a group, the Muslims have experienced historical or political prejudice and mistreatment, and must work harder to ensure their religious identity is recognized.

Regardless of their preferred model of Islam, Muslims in the Rhodopes claim that their beliefs and practices go back to the Qur'an. Salafi Muslims, whose religious life is strongly based on the written word, treat the Qur'an as synonymous with the written text (some hodzhas intersperse their comments with passages from the Qur'an in Arabic). By contrast, Adat Muslims, whose religious life is dominated by the oral tradition, treat of the Qur'an in a much broader sense. "At the same time, each storyteller is convinced that his tale is 'the true one', believing that it springs from the Holy Koran itself, and repeats the sacred utterance of Muhammad word for word" (Badalanova 2001, p. 48). Hodzhas often prefer to cite direct passages from the Qur'an rather than to interpret them in their own way. In our conversations they often cited the same passages twice, first in Arabic and then again in Bulgarian, in an attempt to shore up the orthodoxy of their beliefs, which they are afraid of perverting or corrupting. This also applies to those respondents who have no first-hand knowledge of the Qur'an, and only know it from hodzhas or other people.

Still, many such beliefs are not fully compatible with the written Qur'an in that they venture outside the scriptural canon or motifs analogous to the rich historical-religious writings $^{343}$ and folk literature in Arabic and Turkish, to Christian apocrypha, Midrash, Haggadah and, notably, lives of the prophets (qisas al-anbiya). Particularly influential texts in the latter category seem to include lives of prophets by al-Tha'labi, al-Tabari and al-Rabghuzi, a 14th-century Turkish writer from Western Turkistan, who was familiar with the writings of the former two (cf. Badalanova Geller 2008b, p. 99) $)^{344}$.

Florentina Badalanova proposes the valuable insight that just as the Christian communities in the Balkans have two Bibles (the canonical scriptural text and the folk Bible), similarly the Muslims have two Qur'ans - one based on the canonical Arabic text, and one complemented with biblical and pseudo-biblical narratives (Badalanova 2001). According to Florentina Badalanova, some of the motifs and elements present in the Balkan oral tradition are very archaic, containing elements which are parallel

343 My respondents usually fail to realize those similarities and assume that their religious narratives come exclusively from the Qur'an.

344 In her most recent book (2008b), F. Badalanova Geller analyses Muslim beliefs about the creation of Adam and Hawwa collected in the village of Gorno Kraishte in 2005. Badalanova notes the connections between her material collected from Bulgarian-speaking Muslims and the material collected by J. Knappapert among Egyptian Muslims, and the various lives of the prophets by al-Tha'labi, al-Tabari, al-Rabghuzi. 
to the so-called Ur-hypertext ${ }^{345}$, i.e. the proto-narrative which predated the oral and written fabric of scriptural narratives in the Jewish, Christian and Muslim traditions (Badalanova 2008a, s. 162). The thesis is impossible to verify: the trajectories of those narratives cannot be retraced, and it is difficult to establish whether the oral narratives found in the Rhodopes today are products of a synthesis of Qur'anic elements with other sources ${ }^{346}$, such as commentaries on the Qur'-an (tafsir), histories (tarikh) and lives of the prophets (qisas al-anbiya), but also midrashic texts and hagaddas, the Christian Bible and the Torah - or whether they actually "remember the prototext" which served as a matrix for all those sources ${ }^{347}$ (Badalanova 2001, p. 47). Badalanova believes that all the different layers of the prototext "have functioned throughout centuries independently, yet coherently bound, still evidently retaining certain inner, clandestine links of mutual interdependence, despite of the different languages and dialects through the means of which they were transmitted" (Badalanova Geller 2008b, p. 100). I suppose that narratives parallel to lives of the prophets were not self-generated in the Rhodopes from an original ur-source (or its variants) transmitted locally down the generations, but rather were popularized by the religious elites. A fruitful contribution to the question of provenance could probably come from looking at the historical period of the parents and grandparents of my respondents who shared narratives similar to lives of the prophets: a future interdisciplinary research project into late 19th-century popular religious literature in the Ottoman Empire and early 20th-century popular religious literature in Bulgaria might yield the answer to the question whether lives of the prophets were popular at the time in the general population (or at least familiar to a smaller group of readers).

In my material, my respondents' religious narratives serve primarily to explain the symbolic meaning of the group's religious rites and injunctions, and also to point

345 F. Badalanova believes that such elements, communicated orally by Muslims and Christians in Bulgaria, predate those contained in the Holy Scriptures (Badalanova 2002b, p. 35), the Bible itself being one of the later transformations of the Ur-hypertext (Badalanova Geller 2008b, p. 7). "Unlike their written counterpart, these unwritten Holy Scriptures were extant in many oral versions. Some of them were first registered during the 19th century and published in a number of ethnographic and folklore collections. Anthropological field research in the region of Eurasia indicates that traces of these texts can still be found in indigenous oral traditions; furthermore many new versions can be encountered. These may either reflect canonical or apocryphal accounts of the Bible, or Qur'an and Hadiths, or offer alternatives to them, thereby revealing a previously unknown, cluster of folklore texts related to the Holy Scriptures" (Badalanova 2008 b, p. 7).

346 M. Starowieyski points out that the connections between the Qur'an and the Apocrypha (whether direct or indirect) are beyond doubt, and their contents may have originated in tradition or folklore (cf. Starowieyski 2003, p. 170-180).

347 In the case of legends of the Bible prophets and heroes the latter explanation is particularly likely since "orally transmitted folklore such as proverbs and legends can survive relatively intact for centuries with no help from written sources” (Dundes 1999, p. 10). 
out the other religion's inadequacy. The narratives explicate the meaning of Muslim religious practices necessary for salvation such as kurban, namaz, syunnet, abdest and the covering of the body, and to depreciate Christian practices such as the belief in Jesus Christ as the Son of God, the cult of the Holy Trinity, the sign of the cross or the veneration of icons. In this sense, they are like mythical narratives, "sacred tale[s] about past events which [are] used to justify social action in the present" (Leach, cited in: Badalanova 2001, p. 51).

Some Muslim respondents tell long narratives explaining the origins of Muslim and Christian religious practices. In those narratives Islam is presented as a religion intended by God at the dawn of time (i.e. since Adam and Hawwa ${ }^{348}$ ) and perfectly suited for human needs - unlike Christianity, a religion corrupted by Satan and the teachings of the apostle Paul. In my area of study Muslims tended to invoke two themes in this context: the creation and lapse of Adam and Hawwa, and the sinful humanity in the days of Nuh/Noah (Bulgarian: Noy, Turkish, Arabic and local Muslim version: Nuh). Their narratives sacralize Islam (as the only pure religion which accurately reflects the revealed truth), and desacralize Christianity (as a corrupted quasi-religion), depicting Christians as people who perform false religious gestures based on a misunderstanding of the revealed truth, which the Gospels preserve in a corrupted form. This is combined with a strong need to distinguish themselves from Christian neighbours, who serve as an important reference point. By practising their own religious rites, non-Muslims throw into question the evident nature of Muslim religious practices, prompting a search for explanations which could safeguard the continued existence of a separate Muslim identity. Such explanations are almost never discussed in mixed religious company: Muslims and Christians tend to leave religion and politics out of their conversations. The comments discussed in this chapter were all made in religiously homogenous groups.

Although I am primarily interested in how Muslims use the symbols which position their religious belief vis-a-vis their Christian neighbours, I tried to paint a broader canvas to include the accompanying religious narrative in which such symbols are embedded because such symbols also symbolize the sphere of the sacred (Cichowicz 1985, p. 25) and must be analysed in the religious contexts identified by the respondents to reduce the risk of misreading. To paraphrase Paul Ricoeur, I treat the religious narratives of my respondents as a special symbol embedded in a closely woven narrative tissue. Ricoeur would probably refer to such symbols as myths, i.e. "symbols developed in the forms of narrations and articulated in a time and space". For instance, "exile is a primary symbol of human alienation, but the history of the expulsion of Adam and Eve from Paradise is a mythical narration" which becomes elaborated by the introduction of human characters within time and place and embellished with fantastical episodes: according to Ricoeur, this closely

348 Hawwa is not identified by name in the Qur'an. 
woven narrative tissue is crucial to myth" (Ricoeur 1967, p. 18) (though given the anachronistic ring of the term "myth" I propose the term "religious narrative" as a more neutral alternative in this book).

Although the chapter contains comments by both Adat and Salafi Muslims, the former predominate because my key aim was to distinguish between the basic themes with which Muslims stake out the symbolic boundaries which put them apart from Christians.

In my material, this boundary-making process involves several themes which present Christianity, variously, as: 1) a religion which has broken the promise made by the souls in Paradise, and which abandoned the rituals introduced by Adam and Hawwa, 2) a cult of a false book, 3) an idolatrous cult of the Son of God, initiated by the apostle Paul, or 4) a cult of material objects, a form of sinful iconolatry.

\subsection{Christians as "Perjurers" and "Adam and Hawwa's Worse Children"}

The Muslim narrative of Adam and Hawwa serves to validate the importance of Islam as the oldest and truest of religions, and to depreciate all other religions, Christianity in particular. The present study of the beliefs of Bulgarian-speaking Muslims concerning the creation of Adam and Hawwa is not the first of its kind; the problem has been explored by Galina Lozanova in her book Sŭtvorenyeto v ustnata traditsiya na bŭlgarite myusyulmani (2008) and an earlier article, Sŭtvorenyeto na Adam i Havva v narativnata traditsiya na bŭlgarite myusyulmani (1999). Similarly, Florentina Badalanova's paper The Biblie in the Making: Slavonic Creation Stories (2008a) and book, Qur'an in Vernacular (2008b), are rich sources of material on the subject. However, the narrative variants in those publications are presented in a different context and from a different critical angle. In the present chapter, the narrative of Adam and Hawwa is discussed with regard to questions of ritual ablutions before prayer, the reading of the Qur'an, and the circling of the Kaaba.

I heard the Muslim narrative of Adam and Hawwa from several respondents. The longest version was narrated by bula, a hodzha's daughter born in 1933 in a mixed Muslim-Christian village of Gospodintsi. After getting married at the age of 16 bula moved to Ribnovo where she has lived since. Unwilling to attend a Bulgarian high school, she dropped out of school after completing her primary education. Her elder sister $^{349}$, who studied medicine in Gotse Delchev and qualified as a medical doctor, tried to talk bula out of dropping out, but bula saw continued education as a threat to her religious faith, and chose to live her life according to the will of Allah. She

349 The incident sparked an argument between the sisters, with bula tearing up her sister's diploma to make a point about her own unwillingness to stay in a Bulgarian school. 
believes that the locals in Ribnovo respect her for her religious knowledge, which is comparable to that of a hodzha; she helps the locals by "writing down" prayers for them, so I refer to her as a bula. Bula claims to have received a sign in a dream in which her husband's deceased female cousin gave her a portrait of an angel carrying bula's prayers for other people. Bula says that her extensive knowledge of Islam is based on the Qur'an and stories told by her father, who "used to read her various Muslim books" which he had translated into Bulgarian. With one exception ${ }^{350}$, bula was unable to identify those books by title (Interview 14, Ribnovo 2009).

I suppose bula may have been referring to various lives of the prophets as her narratives contain many parallels with that source (for instance, cf. al-Kisā’’’351 1997, p. 23-55).

Bula's narratives contain motifs such as the creation of Adam and Hawwa, the creation of human souls, and the effects of eating the forbidden fruit, which identify the origins of Muslim religious practices and validate the relative perceptions of Islam and other religions.

To an extent, my respondents' narratives of Adam and Hawwa were compatible with the Qur'an, which mentions events such as the creation of Adam and his wife (3: $59,7: 11,15: 28,38: 75-76^{352}$ ), the angels bowing to Adam and Iblis (Satan) refusing to fall prostrate $(2: 33,7: 11,15: 30-31,17: 61 ; 18: 50,20: 116,38: 73-4,76)$, the expulsion of Satan from Paradise (15: 34, 38: 77), Allah forbidding the first parents to eat the fruit of the forbidden tree $(2: 35,7: 19)$, the creation of humankind and its declaration of faith in Allah (7: 172), Iblis vowing revenge on people (15: 39, 38: 83), seducing the first parents (7: 20), the eating of the forbidden fruit (20: 117-121). The Qur'an is laconic about those events (for instance, it simply says that Satan "brought" people "out" of paradise and "stripp[ed] them of their garments", cf. 2: 36, 7: 27, 7: 22, 20: 121), but many Muslim religious writings offer detailed accounts of those events, complete with detailed descriptions of Adam's food, the name of the wife created from Adam's rib and Iblis's attempts to infiltrate Paradise and seduce the first parents, leading to their fall. Unlike the Qur'an, such narratives split the blame between Adam and Hawwa (Adam is half asleep, not fully aware of the fact that he is eating the forbidden fruit; Hawwa bears more blame because she is inherently more susceptible to sin and manipulation).

This idea is not fully compatible with the Qur'an, where both parents are blamed, but Adam bears more of the responsibility: "Then Satan whispered to him saying,

350 Budilnik na myusulmanite, published (according to my respondent) some twenty years ago. Disappointingly, the respondent could not show the book to me as she had loaned the book to someone.

351 Muhammad Ibn 'Abd Allah al-Kisa'i (13th century) was one of the better-known authors of lives of prophets.

352 Unless they are colloquial paraphrases, all quotations from the Qur'an in this book follow Arthur John Arberry's 1955 translation The Koran Interpreted, available online at http://web.archive.org/ web/20071219022352/http://arthursclassicnovels.com/arthurs/koran/koran-arberry10.html). 
'Adam shall I point thee to the Tree of Eternity, and a Kingdom that decays not?' So the two of them ate of it, and their shameful parts revealed to them, and they took to stitching upon themselves leaves of the Garden. And Adam disobeyed his Lord, and so he erred" (20: 120-121). Those versions which put most of the blame on Hawwa are probably based on the book of Bereshit (Genesis), Christian apocrypha and Jewish midrashic narratives.

Adam and Hawwa are discussed in commentaries on the Qur'an (tafsir), histories (tarikh), lives of the prophets ${ }^{353}$ and, to a much lesser extent, in hadiths. The most famous collection of hadiths by Muhammad Isma'il al-Bukhari (810-870) ${ }^{354}$ only mentions elements connected with the creation of the first people $e^{355}$, leaving out the fall of Adam and Hawwa and the consequences of eating the forbidden fruit.

According to Wilson B. Bishai, Muslim writers writing about Adam and Hawwa were probably inspired by The Life of Adam and Eve $e^{356}\left(5^{\text {th }}-6^{\text {th }} \mathrm{c} \text {. }\right)^{357}$, a Syriac text entitled The Cave of Treasures $\left(6^{\text {th }} \mathrm{c} .\right)^{358}$, and the Coptic text The Encomium of Theodosius on Saint Michael the Archangel (possibly composed in the 6th century) (Bishai 1971, p. 125-128). Presumably, the Slavic apocrypha known in Bulgaria including A Word on Adam and Eve (Slovo za Adam i Eva ot nachaloto do svŭrŝeka, 10-11 ${ }^{\text {th }}$ c.), On the Sea of Tiberias (Za Tiveryadskoto More, probably $11^{\text {th }}-12^{\text {th }}$ c.), A Word from John Chrysostom on How Michael Vanquished Satanael (Slovo na sveti Ioan Zlatoust za tova kak Mihail pobedi Satanata, the earliest known copy dates back to the 16th century), and The Beginning of the World (Pochetiye svyeta), 17th-century manuscript from the Ivan Vazov Library in Plovdiv, probably composed in Bosnia in Bogomil circles (cf. Minczew [Minchev] 2006, p. 26) were indirectly influenced by those sources since they are compilations of earlier texts supplemented with passages composed in Bulgaria (Minczew [Minchev] 2006, p. 3). Given the heterogeneous nature of beliefs concerning Adam and Hawwa, however, it is difficult to identify the different layers or their origins with any degree of certainty.

The narrative elements in my respondent's story of the creation of the first parents as well as her description of their transgression and its consequences betray significant similarities to elements found in Islamic literature. The associated element

353 In the Islamic tradition, Adam was the first man and the first prophet.

354 A Sunni Islamic scholar of Persian descent regarded as the greatest collector of Muslim traditions. His Sahih al-Bukhari, a selection of hadiths, is regarded by Sunni Muslims as an authentic source of hadith traditions. Al-Bukhari also laid down the rules for classifying hadiths and ascertaining their credibility (cf. Danecki 1997, p. 54).

355 It mentions, among other things, the creation of woman out of Adam's rib, which is not found in the Qur'an (4: 55: 548, 7: 62: 114), and Adam's remarkable height of 100 feet (8: 74: 246, 4: 55: 543). 356 Also known as Vita Adae et Euae.

357 The oldest known copy is an Arabic source from the 11th century (Budge 1927, p. 1); the text is available online at http://www.sacred-texts.com/chr/bct/index.htm (20.12.2011).

358 Containing numerous borrowings from the Life of Adam and Eve (Budge 1927, p. XI). 
of the first defecation caused by the eating of the forbidden fruit (leading directly to expulsion from Paradise) was not widely found among my respondents ${ }^{359}$, and the local hodzhas do not in any way consider it to be part of "high" Islamic literature.

$\star \star \star$

In the Muslim oral tradition and in non-Qur'anic literature - inspired by JudaeoChristian legends, Adam is created out of dust (earth), and Adam's wife is made out of one of his ribs. The narrative says that Adam long remained inanimate ${ }^{360}$, like an effigy or a statue. According to different versions, Adam remained in this state for varying periods of time ranging from 400,000 years (cf. Lozanova 2008, p. 51), 70,000 years (cf. Lozanova 1999, p. 285), 40 years (al-Tha'labi Lives of the prophets, cited in: Badalanova 2008, p. 98-9) to 40 days. Adam's soul, which is created later, enters the body gradually so that Adam can gain self-knowledge about his worthlessness because as a being fashioned out of earth (as opposed to angels, who are made of fire):

Bula: Then he pressed on his lower back and he made a soul. [At first] he only placed the soul in his head, so he could see and witness that he was made out of earth. The soul was only in his head. So, he's looking, looking through his eyes, and sees that he's all made of earth. Then he gave him a soul [that came] down to the lower back, and his stomach tightened: he's hungry, but he can't eat. There is no soul in his legs, so he can't walk. He should walk on his legs now, but there's no soul in his legs. (Interview 14, Ribnovo 2005)

The same motif was recorded by Galina Lozanova in the village of Debren near Ribnovo, though her material does not mention Adam's unsuccessful attempt to walk: "The soul comes further down, and he, Adam can see himself transforming, earth into... When the blood reaches him, he can move his arms, [extend them] down, down, all the way down to the big toe ... Adam's soul reached up to here [the neck G.L.], and he sneezed it out and said, 'Thank you, you created me”' (2008, p. 57 [my translation]).

According to Leigh N.B. Chipman, the belief that Adam made unsuccessful attempts to walk before his soul could animate every part of his body is only found in the Muslim tradition and refers to the Qur'an, verses 17: 11, 21: 38 (Chipman 2001, p. 5-25). My respondent's narrative likewise contains an element where all souls are created out of Adam's body by "press[ing] on his lower back":

359 Similar variants of this narrative have been noted by other researchers, including Rachimov, who worked among Tajik Muslims (cf. Wasilewski 1989, p. 187).

360 The Bible also mentions the fact that Adam was first formed "of the dust of the ground" before God breathed the breath of life into his nostrils and he became "a living soul” (Genesis 2, 7, King James Version). The Bible does not explain how long Adam remained inanimate, a problem discussed in many apocrypha, which often claim that man had been somehow tampered with, and deformed by, Satan when left unattended by God (Holy Bible, 1611). 
Bula: And when he pressed on his lower back, all the souls came out like sparks from a fire, like tiny lights out of a fire. In this way, out came all the souls of all the people, the souls of those living today and [those of] the dead, sine [literally: "son", a form of address used by elders when talking to younger people] [until] the Flood. All the souls came out of his lower back. And Allah said, it is written, he said to the angels: make a bow. And they did, only Satan refused and [Allah] expelled him from dzhennet. (Interview 14, Ribnovo 2005)

This motif, though present in the Qur'an (in the passage about the souls created from Adam's loins, 7: 172) has not been attested to date within the oral tradition of Bulgarian-speaking Muslims (cf. Lozanova 2008, p. 72) or in other Muslim religious narratives about Adam. It is also analogous to the kabbalistic belief that all human souls come from Adam as the "primordial man" (Adam Kadmon) in whom "all worlds are reflected" (Unterman 1997, entry for “adam kadmon”). One prevalent idea in Jewish legend is that the souls of all the generations were created along with Adam's soul and are stored in the seventh of the heavens, awaiting incarnation (Ginzberg 2005, p. 56). In bula's version this happened in Paradise, whereas Islamic writings tend to say that the souls were extracted from Adam after his expulsion from Paradise: as Allah struck Adam's lower back (or, in a version attested by Galina Lozanova, simply his back), all of humanity issued out of Adam's back, the people small as ants, and professed their belief in Allah by reciting the shahadah ${ }^{361}$ before returning to Adam's loins:

Bula: And this is what he said to the little souls: "Will you observe my commandments, as I announce them one by one? Will you say the prayers? Will you study the Qur'an? Will you do that?" And the souls made the promise. All right, then. Our souls had made the promise, but we aren't keeping that promise. This is why we will be punished, this is the reason. Because we made the promise. The soul promised to keep Allah's commandments, and now it does not. Christians, Gypsies, Jews, Muslims. Even Muslims, many of them, aren't keeping the promise. Many of them aren't. They will be punished. You find believers among Christians and non-believers among our people. (Interview 14, Ribnovo 2005)

Hodzha 6: 50,000 years ago, before Allah, God, created the earth and the seven heavens, he created your soul and mine. Perhaps our souls were together back then. Do you understand what I'm saying?! Then God asked us the question: "If I create you and send you to earth to live there as a test, will you keep my injunctions and prohibitions?” At that point your soul said, "I will, my God. I will, my God". All the souls said the same thing, they said yes. "We will keep your commandments". 50,000 years ago, before God created the Earth and the seven heavens, in an unknown space, we don't know where it is. Do you understand? At that time God posed the question to you. And what is it that we're doing today?! What are we doing?! (Interview 30, Satovcha 2005)

361 According to some traditions, only the souls standing to Adam's right side recited the shahadah (the Islamic creed, the declaration that "there is no god but God, Muhammad is his prophet"); those on his left did not, and were condemned by Allah (cf. Weil 1863, p. 39). An English translation is available online at http://www.sacred-texts.com/isl/bkt/bkt04.htm (19.02.2012). 
The belief that Islam is a religion of all the human souls is an elaboration of a motif from the Qur'an, according to which all human souls had promised to embrace monotheism: "And when thy Lord took from the Children of Adam, from their loins, their seed, and made them testify touching themselves, 'Am I not your Lord?' They said, 'Yes, we testify' - lest you should say on the Day of Resurrection, 'As for us, we were heedless of this,' or lest you say, 'Our fathers were idolaters aforetime, and we were seed after them. What, wilt Thou then destroy us for the deeds of the vaindoers?" (7: 172-173). According to Galina Lozanova, this view is expressed in an oftenquoted hadith (which I also heard in my field research) that every child is born a Muslim (which Lozanova interprets as essentially meaning a monotheist) but may be raised in a different religion by its parents (cf. Lozanova 2008, p. 72).

Other narrative elements, not found in my respondent's version, can also be found in Muslim religious literature, identifying Islam as a religion assigned by God and going all the back to the beginnings of humanity ${ }^{362}$ : the shahadah (the Muslim confession of faith) is written on Allah's throne, Adam's head and his heart are fashioned out of earth collected at $\mathrm{Mecca}^{363}$, Adam sees the light of the prophet Muhammad in heaven, Adam and Hawwa are hailed as Muhammad's parents; when the soul fills Adam's body completely he sneezes, praising God with the Muslim formula al-hamdu li-llah ${ }^{364}$.

My respondents' narrative also contains a Jewish element found in the oral tradition of Bulgarian-speaking Muslims (cf. Unterman 1997, p. 13), where the Angels bow down to Adam, but Iblis "waxes proud" and refuses to do so. For his refusal to prostrate himself, Iblis is punished by God and expelled from Paradise (2: 34, 7: 11). Filled with regret and envy, Iblis plots to enter Paradise and deceive Hawwa.

As in Judaism or Christianity, Iblis tempts Adam and Hawwa with the fruit of the forbidden tree. The Qur'an does not mention the name of the forbidden tree or describe the temptation scene; there is no mention of the snake, and the whole event is enigmatically referred to as a "slipping" from paradise $(2: 36)^{365}$. To satisfy pious

362 My Christian respondents did not make a point of Christianity،s superiority over Islam, which they could have done by citing such analogous Christian apocryphal narratives as The Sea of Tiberias, where Christianity is presented as the religion God originally intended to be the religion of salvation: "He put Adam to sleep and took a rib from him and created a wife for him. And God asked Adam 'Adam, what did you see in your dream?'. And Adam said, “God, I saw the apostle Peter in Rome being crucified with his head down and \{I saw the Apostle Paul in Damascus. I saw John in Edessa and You, God, in Jerusalem on Golgotha being crucified on a cross and pierced with a lance in Your rib"” (a passage from the apocryphal The Sea of Tiberias, translated by Florentina Badalanova Geller from a 16th-century Russian redaction, see Badalanova Geller 2011, p. 120).

363 In Jewish versions the location is identified as Mount Moriah or Jerusalem.

364 Praise God / thank God.

365 “Then Satan caused them to slip therefrom and brought them out of that they were in". 
curiosity, more details are provided elsewhere in non-canonical Islamic legends like qisas al-anbiya (al-Tha'labi 2002, p. 49), showing clear analogies to The Cave of Treasures, except in the latter Satan additionally asks other creatures to take him into Paradise, including various birds, the elephant, the lion, the hyena, the wild boar and a mysterious animal called Taman (Budge 1927, p. 65-66).

In those legends and oral narratives of Bulgarian-speaking Muslims, Satan gets into Paradise by attempting to bribe the guards: the peacock ${ }^{366}$ or the serpent, identified in my respondent's version with the lamia, a mythological monster ${ }^{367}$. Satan first promises immortality to the peacock (by showing it the tree of immortality or, in my respondent's version, by telling him three secret words) in exchange for letting him in, but the peacock sends Satan back to the serpent/lamia. The serpent/lamia, a guard of Paradise and a friend of Hawwa ${ }^{368}$. is the only creature in Paradise who agrees to smuggle Satan into Paradise in her mouth or belly ${ }^{369}$. Before being punished by God for her conspiracy she was the queen of the animals, a creature of extraordinary beauty. Hidden in the lamia's mouth, Satan impersonates her to deceive Hawwa:

Bula: "Havva, we have been great friends, but there are three things you don't know, and I must tell you about them. There is a certain tree here, she says, and you were told not to eat of its fruit. But there is a man there who, like you two, was created in Paradise" - we call that $d z h e n n e t$, you

366 According to K. Tisdall, the peacock is a Zoroastrian influence, where he symbolised evil (Ariman, cited in: Lozanova 2008, p. 99).

367 The word lamia is originally Greek. In Greek mythology, Lamia is known as a lover of Zeus and a female ruler of Libya who turns into a monster and murderer of children and young men after the jealous Hera kills her children. Lamia was imagined to be a hybrid with a female head, animal limbs, a tale, wings and a scaly body. In Bulgarian mythology, the lamia is usually a serpent-like creature believed to bring hailstorms and bad harvests (Benovska-Sabkova 1995, 60-61). As my material suggests, the lamia may also be associated with the serpent of Paradise (Bulganian: zmiya). In Bulgarian, the words for snake (zmiya) and lamia are both feminine, so the serpent is a plausible female friend for Eve.

368 The commentator Heronymus (4th century) identified the Greek Lamia with Lilith, initially Adam's first wife, later a night monster and baby-snatching demon (Graves, Patai 1964, p. 68). Unlike Eve, she was not created from Adam's rib but from filth and sediment (while Adam from pure dust), so they were almost equals. According to some Hebrew myths, "Adam and Lilith never found peace together; for when he wished to lie with her, she took offence at the recumbent posture he demanded. ,Why must I lie beneath you?' she asked. ,I also was made from dust, and am therefore your equal. Because Adam tried to compel her obedience by force, Lilith, in a rage, uttered the magic name of God, rose into the air and left him" (Graves, Patai 1964, p. 65-6). Lilith is presented as a kind of archetypal feminist in this narrative, and Lamia, Lilith's friend, need not be a friend of Eve. The motif of admitting Satan into one's body, expressed through a story of Satan being smuggled into Paradise in the mouth, can be treated as a symbolic story of lamia's voluntary possession which turned her into a tool of Satan as her desire for secret knowledge outweighed her loyalty to a friend/rival (either sexual or intellectual, hoping to possess Satan's secret knowledge). Interestingly, in al-Tha'labi's lives of the prophets the serpent is a friend not of Hawwa but of Iblis, whom he smuggles into Paradise in his mouth, similar to my respondents' narrative (al-Tha'labi 2002, p. 50-51).

369 In other legends she does it unwittingly (cf. Lozanova 2008, p. 98). 
call it Paradise [a clarification from the respondent - M.L.] - and he eats of that tree, and he's been there forever. He's been in dzhennet these three thousand years, eating of that tree. "You can come along if you like, you'll see that the man is just like you two, and he eats of the tree, living for eternity in dzhennet, in Paradise". All right then, but when they reached the tree, he came out of the lamia's mouth and turned into a man. Being a melyeke, an angel, he can turn into anything. A man, an animal, anything.

M.L.: But how do you know all that? Is that in the Qur'an, too?

Bula: All this is in the Qur'an. An angel can turn into anything, an animal, a man, anything at all. So, he's turned into a man, and he's walking around the tree, and sits down. (Interview 13, Ribnovo 2005)

An iconographic depiction known in Bulgaria shows a snake with a human head coiled around a tree (for instance, an icon in the church in Arbanasi shows a human head sticking out of the snake's mouth).

Apocryphal writings explicate the motif: "So the devil appeared in Paradise in the form of a serpent called the beautiful virgin as she was created with a female head" (Poczatki... 2006, p. 28 [translated from Polish]). In other apocryphal writings, Satan hides in the snake's mouth or belly, rather than turns into a serpent:

Hodzha 4: This Satan enters the serpent's belly. Because Satan can take on any form he likes, a melekyeto [Turkish: melek, Arabic: malak - angel - M.L.] can turn into anything. (Interview 3, Ribnovo 2005)

"At that time in the Paradise the serpent was the most reputable among animals and the most handsome. The serpent went out of Paradise for a walk, Satan from the very beginning hated that good in mankind, and Sotona turned himself into a worm and crawled to the serpent and said to the serpent' "Eat me". It [in the Old Church Slavonic the noun depicting serpent is feminine - F.B.] ate the worm and took it into Paradise. The serpent then coiled araound the forbidden tree and Sotona started calling out from the serpent mouth" (The Sea of Tiberias, see Badalanova Geller 2011, p. 122). However, my respondent's narrative can serve as a possible exegesis of the scene, where Satan leave's the serpent's body near the tree and appears to Hawwa in a human form to tempt her:

Bula: [Satan - M.L.] sat under the tree, and when they drew near, the serpent and azreti Havva, they look, and they do indeed find a man under the tree. "I am human like you, created three thousand years ago, and I am here. I was forbidden [to touch] this tree, but I eat of it and I live here eternally. Go on, have some. You were told not to eat of the sweetest tree. Pluck [a fruit] and taste how sweet it is ${ }^{370}$. And Havva ${ }^{371}$ plucks one, and eats it. "All right, let me go to my husband,

370 G. Lozanova mentions a similar element in a narrative told by her respondent, Moarem Pahedzhi from the village of Debren: “This is the sweetest apple, bite it” (cited in: Lozanova 2008, p. 100).

371 Possibly for my sake, the respondent alternated between the Arabic and Bulgarian versions of the name, which she uses interchangeably. F. Badalanova had a similar experience (Badalanova 2008a, p. 106). 
and tell him to have some, too". He was sleepy, but he got up. He went and when he ate it... What is it that you find here, in a man's [throat]? [the respondent points to her larynx]? That's because of the apple ${ }^{372}$.

\section{M.L.: Why did he listen to her?}

Bula: He was sleepy, he was asleep and didn't realize it was [the fruit] of the forbidden tree. But he realized he had committed a sin.

M.L.: You mean, he didn’t realize she was giving him a fruit from the forbidden tree?

Bula: Exactly. (Interview 13, Ribnovo 2005)

Rather than impersonate a human being, the Satan of Muslim legend and Christian apocrypha takes on the form of an angel ${ }^{373}$ or an angel with a face of a man (to convince Hawwa that he had turned into an angel after eating the fruit of the forbidden tree ${ }^{374}$ ). According to other variants known in the Balkans, Adam did not finish the fruit: this element appears in the well-known apocryphal text The Beginnings of the World (Poczatki... / Pochetiye svyeta) where Adam bites the apple and, remembering God's words, chokes on the fruit. The eating of the forbidden fruit makes Adam and Eve sinful and naked (Początki..., p. 29):

Bula: They can be small, they can be large, they can turn into anything. So, he enters $d z$ hennet and begins to persuade Adam to pick a fruit from the tree and eat it. All right, but he refused. So he persuaded the woman. A woman is more amenable [to persuasion], he talked her into that. "This is the prettiest tree. He forbids you to eat of it. Go on, have some, taste it". She took some and tasted it. "Azreti" Adam was asleep, and she woke him up. "Get up and taste this, just look at this comely tree. And she gave him some [fruit]. "Here, taste it, it’s delicious”. He took a bite, and immediately realized that Allah had forbidden them to eat of it, that he would be punished for this. As he swallowed, a piece stuck in his throat here. Women don't have this, but he had this bit stuck in his throat. He was trying to spit it out and hide it from Allah. (Interview 13, Ribnovo 2005)

According to al-Tabari, Adam tasted the forbidden fruit after drinking wine provided by Hawwa, who had realized Adam would never have done that while sober (al-Ṭabarī 1989, p. 279).

372 Ayshe from Satovcha identified the forbidden fruit as an olive.

373 (Cf. Stowo... 2006, p. 32, 42).

374 The Qur'an either does not identify the tree at all (7:19) or refers to it as "the Tree of Eternity" (20: 120). In al-Tha'labi's it is called "the tree of immortal life" or "the tree of eternal life" (al-Tha'labi 2002, p. 50-51) and in al-Tabari, "the forbidden tree” (al-Ṭabarī, 1989 p. 129). 
In other words, Islamic legends primarily blame Hawwa for the original $\sin ^{375}$, which explains why the religion places the most demanding religious duties on women. This interpretation is not compatible with the Qur'an, which splits the blame between Adam and his wife.

I also encountered another variant of the narrative, in which only Adam ate of the forbidden tree, and was expelled from Paradise alone:

M.L.: But what happened after he followed the call and God...

A.: God punished him, expelled him from the garden of Paradise.

M.L.: And what about Havva?

A.: Havva was not [expelled]. She committed no sin, she did not bite [the fruit] or ever did anything impure. He was the only one chased out the garden of Paradise. There's something else but I don't know ...

M.L.: You mean, she stayed in Paradise?

A.: So I heard. Perhaps there was more to it, but I've forgotten it. It's an old story, my grandmother told it to me. (W, M, Interview 24, Satovcha 2005)

In bula's narrative, Adam and Hawwa eat the fruit and react with immediate horror. Adam is more fully aware of the consequences of their transgression. Contrary to the version in the Qur'an, all of humanity inherits the blame in her narrative: after the first parents eat of the forbidden fruit, those parts of the body which caused the transgression must be ritually cleansed:

Bula: He became awake, came to his senses and realized that it was the [forbidden] tree [they were eating from]. "Hey, what have we done! Haram". He made a gesture with his hand, like this [the respondent clutches her head]. We wash our hands because they picked [the fruit] of that tree. We rinse our mouth because they ate it. We clean our noses because the nose smelled [the fruit] of the tree. This is the point of abdest, to cleanse oneself of all sins before prayer.

M.L.: Do you wash the nose as well?

Bula: Yes, three times.

M.L.: And why the head?

375 According to my Muslim respondents, this is because of Eve's stupidity. "He could never have deceived a man. A man has nine times the amount of sense that a woman does. It says so in the Qur'an" (Interview 13, Ribnovo 2005). Cf. the material collected by G. Lozanova (Lozanova 2008, p. 100). 
Bula: That's because he said, “Alas, what have we done!” Haram! So. That's why you need water. For our ears, because we listened to Satan, and for this bit here, above the eyes, because we stared. And the ears, like so [demonstrates - M.L.], all the way to the back of your neck. And you say this. You perform abdest so that all the sins fall away, and then you can say your prayers without sin. So Allah accepts it. (Interview 13, Ribnovo 2005)

Because Adam and Eve's defilement affects all of mankind, Christian prayers are inferior because they involve no abdest to guarantee ritual purity through the gestures which, to Muslims, symbolically restore the edenic purity of the worshipper's body and spirit ${ }^{376}$. The motif of ritual purification by immersion in water is also known in Jewish legends ${ }^{377}$, and in Slovo za Adam i Eva ot nachaloto do svŭrŝeka (cf. Stowo... 2006, p. 42).

The Qur'an does not posit a link between Muslim religious practices and the sin of the first parents, and refers to ablutions as a precondition for prayer in unrelated passages (Suras 4: 43, 5:6, and 22: 29): "O believers, when you stand up to pray wash your faces, and your hands up to the elbows, and wipe your heads, and your feet up to the ankles...” (5: 6).

According to my respondent, sin brought about the spiritual and corporal shame of human physiology. Unlike all previous foods, the fruit of the forbidden tree led to defecation, a symbol of impurity and $\sin ^{378}$. From this moment on people, unlike angels, became impure (al-Tabarī 1989, p.108, Badalanova 2008, p. 102; Wheeler 2004). Because there "must be no faeces in Paradise" they were expelled (al-Tabarî 1989, p. 108).

Another respondent, Ayshe of Satovcha, said that Adam needed to urinate after eating the forbidden fruit (an olive in her version). Adam tried to hide and met God, who asked him about his unpleasant body odor. Adam failed to confess his sin, and was duly punished:

A.: He ate that olive and went to take a pee, to relieve himself. He kept walking and walking, looking and looking, he disappeared into some hiding place. But God came and said, "Adam,

376 Ablutions are closely connected with the prayer which follows, and which can be considered part of it. As a form of contact with the sacred, Wasilewski points out, prayer should be wrapped in the same kind of ideal reality as the mythical time of beginning (cf. Wasilewski 1989, p. 76-77), so the obligation to perform ablutions before prayer sets the scene for a model, sacred situation untainted by any impurity (cf. Wasilewski 1989, p. 44, 8).

377 Adam realised that Eve would be unable to mortify her body. As penance he told her to "[a]rise, and go to the Tigris, take a stone and stand upon in the deepest part of the river , where the water will reach as high as thy neck. And let no' speech issue forth from thy mouth, for we are unworthy to supplicate God, our lips are unclean by reason of a forbidden fruit of the tree” (Ginzberg 2005, p. 87). 378 Importantly, the new generation of young hodzhas in the Western Rhodopes dismiss this element as a worthless local folk tradition, without realising that it appears in al-Tabari, who quotes it on the authority of Abu al-'Aliyah (al-Ṭabarī 1989, p. 108, 280; cf. also Wheeler 2004, p. 89-119). 
what's that unpleasant smell?”. "It's nothing. There's no unpleasant smell”. Then he punished him. He expelled him from the garden of Paradise. I don't remember what happened next. (W, M, Interview 24, Satovcha 2005)

In bula's version, the attempt to conceal the physiological effects of sin produced hair on the head, in the armpits and around the genitals, leading to another religious duty being imposed on the first parents. Her version treats hair as the most impure part of the human body, a kind of stigma caused by the eating of the forbidden tree and a remnant of the faecal matter Adam and Hawwa rubbed into parts of their bodies when trying to conceal their shame:

Bula: Now, after they'd sinned, they needed to relieve themselves. Unlike the fruit they used to eat [before - M.L.], which never made them go. So, what should they do? It was a clean place, such things were unknown ... so they took this thing, and started rubbing it into their heads, under the armpits, around their intimate parts... That's why it's sinful today, hair is [a product] of sin. A woman's hair shouldn't be seen. The woman ate a whole fruit and started rubbing it into her head, into her armpits, around her intimate parts. And her husband here, below the head, that's why they shave now to get rid of it. That's why it's sinful to show your hair. For every hair a woman exposes, a serpent will [torment her] in dzhennet, in hell. (Interview 13, Ribnovo 2005)

Similar narratives were recorded by the Bulgarian folklorist Evgeniya Mitseva in the village of Chernoglavtsi (Shumen province) in 1987 and by Florentina Badalanova in the village of Gorno Kraishte near Blagoevgrad in 2005:

...Then God said to Adem [one of the local variants of the name, probably from Turkish: ÂdemM.L.], and Havva, "You can eat from everything here, but you shouldn't eat the wheat from the wheat-tree!”, [which is the ear of grain] from which we now make bread. Because, when you eat it you have to go to the toilet, yet there [in Paradise] there were no toilets. So far so good, but Sheitan said to Eva first of all, "Eat from this, see what it tastes like." Eva ate; so far so good. But then Eva also said to Adam, "Eat from this wheat, see what it tastes like." As soon as Adem ate, he immediately felt [that he had done something he should not have done], because God had said not to eat [from the wheat]. He caught himself "here" [storyteller indicating his Adam's apple], and now men have a bone there which women lack. Having eaten, they needed the toilet. Where could he go? He had a hat on his head, didn't he? I don't know what it was like then, but he hid whatever he could [storyteller indicating his face and armpits and groin]. This is where body hair grew. This is why Adem has a beard while women don't; Eva didn't do that [touching her face], knowing that her hands were dirty. (AIF, No. 4, recorded by Evgenia Mitseva, cited in: Badalanova Geller 2008b, p. 13-14. All explanations in the square brackets in this passage are from the original source)

And they are from a tree. But He had ordered [beforehand], “Don’t eat from this tree!” because then they will defecate, they will relieve themselves. And then they ate from this tree and they relieved themselves, and they put some [of their excrement] here [gesturing: under one armpit] and then here [gesturing: under the other armpit] and here [gesturing: between their legs] and hair grew there. Hair grew [here and there] on us [i.e. mortals] and He chased us away, Allah chased them away from Paradise. (Gorno Kraishte 2005, cited in: Badalanova Geller 2008b, p. 11; All explanations in the square brackets in this passage are from the original source) 
As Badalanova explains, "The idea that pubic hair and armpit hair are bodily representations of the Fall and loss of innocence is further related to vernacular interpretations of purification customs. This is why the removal of body hair during certain Islamic rites and ceremonies (including suicide attacks) is considered to be one of the means of re-acquiring Eden-like purity” (Badalanova Geller 2008 b, p. 102, n. 35).

In bula's narrative, Eve, who was deceived by Satan and swallowed the fruit in its entirety, exposed herself to more physiological and spiritual impurity ${ }^{379}$ :

Bula: Those things are haram to women but not to men. For a woman, it's sinful to expose her hair. And she can only expose her hands up to here. We, women, have to be covered ${ }^{380}$, because it was a woman who gave rise to haram. She ate a fruit of that tree. (Interview 14, Ribnovo 2005)

Hawwa also showed less remorse than Adam, who made a futile attempt to cleanse himself by spitting for thirty days, hoping to spit out the food his wife had tricked him into accepting. This explains why "the Turks" fast for thirty days ${ }^{381}$ : ritual defilement serves to provide an explanation for the origins and significance of the Ramadan.

According to some Muslim sources, Hawwa's menstruation was another consequence of the original sin; in this interpretation, menstruation is an echo of the body ejecting the pips of the forbidden fruit (cf. Lozanova 1999, p. 293). In The History of al-Tabari, menstruation is explained as a form of divine punishment on Hawwa after she "caused the tree to bleed" by plucking the forbidden fruit. As an additional punishment, some of Hawwa's intelligence was taken away, and she had to labour in childbirth (Al-Tabarī 1989, p. 278-281).

Implicitly, the eating of the forbidden fruit is connected with the first parents' sexual initiation (Adam and Hawwa realize that they are naked). In folk tradition, this passage is given a literal interpretation: Adam and Hawwa physically "shed" a kind of prelapsarian epidermis, similar to hair or fingernails. In my respondents' narratives, hair is believed to have been formed out of faecal matter, representing the most impure aspects of humanity. Hair removal is seen as a hygiene procedure to remove the "effects of sin", and the obligation to cover or shave one's hair implies religion's social control over sexuality.

In other ethnographic material collected in Bulgaria, hair is sometimes treated as a remnant of prelapsarian skin rather than a product of lapsarian impurity ${ }^{382}$ :

379 Some Muslim legends say that Adam had more of the fruit.

380 As my respondent goes on to explain, Adam and Eve covered the nakedness with fig leaves because other trees of Paradise refused to give them leaves.

381 AIF, no 69, Blagoevgrad, recorded by E. Mitseva.

382 In my respondents version, fingernails and toenails rather than hair are the remnant of the skin of Paradise. This belief can be found in Jewish legends and in the Qur'an (7: 22), in tafsir (Arabic: tafsir) of al-Tabari in lives of the prophets by al-Tha'labi (Wheeler 2004). Al-Tabari adds that the genitals 
"Yes, that's what the serpent told me, if we bite the fruit we'll see God. And so he was persuaded. When they took a bite, their hair fell away; they clutched their heads, and the hair on their heads stayed on, and in the armpits, where they pressed [their arms against the body]. Wherever they covered themselves, the hair remained" (Lozanova 2008, p. 293, translated from Bulgarian).

A Bulgarian scholar recorded a similar element in the late 1970s in the Orthodox Christian community in Hadzhidimovo:

He goes and plucks from that tree - and just as we used to have hair all over the body, all that fell off. Only here, in the hidden places... See, here in the armpit, down below, here [pointing to the armpoit and below the groin - D.D.]. She became embarrassed and covered her head like so... [hides her intimate parts with both hands - D.D.]. She wore a kerchief... only here the wool stayed, and we became naked. Before that we had pelts, too. (AIF, no. 75, Hadzhidimovo 1979, recorded by D.D. - translated from Bulgarian)

This coexistence of narratives which take diametrically opposed perspectives on human hair results from cultural ambivalence about hair, a body part which resists easy categorization: hair is a liminal thing, which can be treated as sacred or impure in different contexts.

In my respondents' narrative, Adam and Hawwa's sexual initiation has another ritual consequence, namely the need to perform ritual ablutions after intercourse. Failing to do so would be a sin, whether to Christians or to Muslims:

M.L.: Can you tell me what else they [Christians] have failed to accept?

Bula: They’ve failed to accept... if you will forgive me, but when a man and a woman come together, they take a bath afterwards, because it's sinful. They [Christians] haven't adopted that [practice]. They go to take a bath on Sundays. (Interview 13, Ribnovo 2005)

The notion that Christians only wash on Sundays probably stems from the respondent's mistaken belief that hygiene forms part of Christian religious practice (as a precondition for visiting a church), as is the case in Islam. The presumed fact that Christians appear to only engage in that practice on Sundays suggests bodily and spiritual impurity.

The narrative told by my respondent from Ribnovo (which provides most of the material in this analysis) seems to be based almost entirely on motifs known in the Islamic tradition as early as the $8^{\text {th }}-10^{\text {th }}$ centuries. It is not clear whether this stems from the oral tradition, old Ottoman religious writings (kept at home by some of the older hodzhas, who pass down their contents in mosques) or modern sources

were blocked by nails covering them, which is why Adam and Hawwa did not realize they had them (Wheeler 2004). This element is echoed in the prohibition to cut one's hair, pare one's fingernails or use perfume when performing the Hajj (Wheeler 2004). 
(e.g. Muslim press), the latter possibility probably being the least likely of the three, as Muslim journals tend to be mouthpieces for "Salafi Islam".

My respondent's idea that certain religious practices could be traced back to the sin of the first parents and its consequences is incompatible with orthodox Islam, which does not accept the concept of the original sin. Elements such as abdest (understood as cleansing those parts of the body which became contaminated by eating the forbidden fruit) or the origins of human hair and the obligation for females to cover their hair to conceal it from other people's gaze (supposedly as a result of the stigma of the forbidden fruit) are not popular narrative components in stories about Adam and Hawwa. They are not mentioned by Galina Lozanova or Leigh N.B. Chipman in the comparative studies of Jewish and Muslim folklore or by Gustav Weil. However, they can be found in the writings of such well-known Muslim writers as al-Tabari and al-Tha'labi.

The explanation for ritual ablution as offered in this narrative is an interesting example of how religious diversity can be dealt with in an area marked by mixed Islamic and Christian influence. Muslim ritual is validated by its identification with the sacred event, and Christianity is portrayed as incomplete and deficient. The narrative portrays Christians as people who have "forgotten" the promises they made in Paradise and the foundational religious events which lie at the heart of religious practice. By failing to perform ablutions, Christians bear the mark of sin at all times, and can never hope to achieve the purity of Paradise. Their religion is deformed, a twisted and incomplete "empty gesture".

\subsection{Worshippers of an "Inferior Book"? Muslims, Christians and a Dispute over God's True Word}

For the Christian this universal Word is appropriately identified with Jesus of Nazareth. For the Muslim it is the Quran as conveyed through Muhammad (Nasr 2000, p. xviii)

According to Seyyed H. Nasr, the Qur'an is to Muslims a central theophany of Islam (Nasr 1998, p. 43), equivalent to the theophany of Christ in Christianity ${ }^{383}$. Rollin

383 I agree with S.H. Nasr that "One could, of course, make a comparison between Islam and Chrisianity by comaring the Prophet to Christ, the Qur'an to the New Testament, Gabriel to Holy Spirit, the Arabic language to Aramaic, the language spoken. In this way the sacred book of one religion would correspond to the sacred book of other religion, the central figure in one religion to the central figure in other reiligion and so on. But in order to understand what the Qur'an means to Muslims and why the Prophet is believed to be unlettered according to Islamic belief, it is more significant to consider this comparison from another point of view". Therefore Nasr writes that "The Word of 
Armour notes this analogy: "the exalted status of the Qur'an becomes clear if one asks for the Islamic parallel to Jesus. The answer is not Muhammad but the Qur'an. Muhammad is a prophet and, like Paul or Mark of the New Testament, a human being, inspired but not divine, a person who announces a holy revelation. The Qur'an, however, is the divine revelation itself, the eternal Word of God in human language, just as Jesus in Christian teaching is the eternal Word of God in human form" (Armour 2002, p. 14).

For Muslims, God's grace operates through Word (the Qur'an) ${ }^{384}$, while for Christians it works mostly through Image (as in the case of icons). At the same time, in terms of religious practice, both objects are treated in a sensory manner: the act of kissing an icon (Orthodox Christians), carrying a piece of paper with verses from the Qur'an or rinsing one's face with water in which such a piece of paper had been submerged (Muslims) may bring healing from various physical and psychological conditions.

To an even greater degree, the same seems to apply to the black stone in the Kaaba whose cult is in some ways analogous to the cult of icons in Orthodox Christianity. As with the icons, the faithful have special sensory relationship with the object, coupled with a belief that by touching it they are accessing a different dimension of reality. This is what the hodzha refers to in the following passage:

Hodzha 1: The Kaaba is a building the size of a house, like a square, and there is this black stone attached to one of the corners; it's not an earthly stone, it's a stone from heaven.

M.L.: And it's attached to one of the walls?

H.1: Yes. On the side, in the corner. All comers may touch it and kiss it. If you can't kiss it, you can touch it. If you can't touch it, you just reach out in its direction. Every time you make a circle around it.

M.L.: Why?

H.1: Because it's a heavenly stone, a divine stone ... I don't know exactly.

M.L.: In which case it would seem to me that it's very much like an icon.

H.1: Logically speaking, yes. (Interview 10, Ribnovo 2005)

God in Islam is the Qur'an, in Christianity it is Christ. The vehicle of Divine Message in Christianity is Maryam Mary, in Islam it is the Soul of the Prophet. The Blessed Prophet must be unlettered for the same reason that the Virgin Mary must be a Virgin” (p. 32). Accordingly, in the following sections of the book I mention examples of such comparisons I encountered in the Rhodopes.

384 In "Adat Islam”, this also applies to the Qur'an as Word materialized, as evidenced by the practice of wearing muskas (special passages of the Qur'an) to protect oneself from malign supernatural powers. 
The hodzha admits that there might be an analogy between the Muslim cult of the black stone in the Kaaba and the cult of religious icons, but he points out the many differences:

Hodzha 1: No, you don't expect anything from it, you just venerate it because it's not an earthly stone. You don't say any kind of prayers in front of it. The prayers... when you are circling the Kaaba you only ever pray to Allah. You might see people who have circled the Kaaba and have put their hands on the stone to pray, but someone always comes up to say, “Don't do that! This can't help you. The stone can't help you. Pray to the Highest, you are in a place where your prayer is most likely to be heard. But you shouldn't pray to the building”. Because there are people who come and cling to the building, they pray to the building. As if they thought the Highest was inside... (Interview 10, Ribnovo 2005)

At the level of local re-interpretation by people from different religious groups, analogies between the religions are more schematic, mostly based on superficial observations of the religious practices of neighbours. One of the most frequent analogies I discovered involved the Gospels and the Qur'an.

According to my Muslim respondents, the Qur'an is the only book to accurately reflect revealed Truth. The Qur'an describes itself as a book unto which God "has not assigned ... any crookedness" (18: 1$)^{385}$ : the most perfect of books, the only book untainted by human interference. The Qur'an frequently mentions its superiority to all earlier books (cf. Suras 3: $3^{386}, 7^{387}, 23,110 ; 4: 82 ; 6: 59,89,154,156 ; 8: 196 ; 9: 111$; 10: 37, 38; 14: 64).

According to a hodzha from Ribnovo, a massive effort of scholarship once confirmed that different Arabic texts of the Qur'an were perfectly consistent with one another:

Hodzha 2: In the 19th century, they had gathered in Munich 40,000 Qur'ans from all over the world. This writer and that, and that, they all spent fifty years working on [those books]. Everything had been retained, and there were no changes. It's all kept in an archive in Munich to this day. (Interview 19, Ribnovo 2005)

According to the mufti (head of the Muslim community) in Gotse Delchev, the Qur'an could only retain such pristine textual purity by divine providence:

Mufti: I mean, Allah is the one who sent the Qur'an and he has safeguarded it. I mean, not one dot has changed in the Qur'an for 1400 years. (Interview 18, Ribnovo 2005)

385 Praise belongs to God who has sent down upon His servant the Book and has not assigned unto it any crookedness (18: 1$)$.

386 "He has sent down upon thee the Book with the truth, confirming what was before it, and He sent down the Torah and the Gospel aforetime."

387 "It is He who sent down upon thee the Book, wherein are verses clear that are the Essence of the Book, and others ambiguous.” 
The fate of the earlier sacred books and of the Qur'an is in God's hands: "God blots out, and He establishes whatsoever He will; and with Him is the Essence of the Book" (13: 39).

Muslims believe that the prototype of all the divinely revealed books, known as the Mother of the Book (Umm al-Kitab ${ }^{388}$ ), exists in heaven: "This [Qur'an] could not have been forged apart from God; but it is a confirmation of what is before it, and a distinguishing of the Book, wherein is no doubt, from the Lord of all Being" (10: 37); "And We have sent down to thee the Book with the truth, confirming the Book that was before it, and assuring it" (5: 48). The fact that "the Book" is referred to in the singular suggests a belief that an archetype exists, which is reflected in all other sacred writings, all of which except the Qur'an have been lost, distorted or squandered by humanity.

According to one hodzha, Allah sent instructions on religious worship to every tribe on earth, initially contained on several pages, and then, once the earth had been fully populated, in four consecutive books:

\section{M.L.: What kind of book did Adam receive?}

Hodzha 1: Tasalfah [the respondent speaks indistinctly. The word is probably related to the Arabic root salafa (to precede) as the book of Adam was supposedly the first book revealed by God M.L.]. Just a few pages that his tribe needed. I mean, the earlier prophets had been sent [several] pages [each], but finally, when society had grown, four books were sent, one after another. But Allah used to send pages to every tribe, showing people how to live, how to be useful to each other and to society. (Interview 10, Ribnovo 2005)

My respondents believe that the Qur'an alone contains the revealed Truth and preserves fully the most valuable elements from the earlier scriptures. For this reason, God intended the Qur'an to serve all worshippers of the revealed religions, including Christianity. With the arrival of the Qur'an, the Christians were faced with a choice: they could either persist in their erroneous evangelical doctrines or embrace the message of the Qur'an and convert to Islam. From that moment, says a hodzha from Ribnovo, the word “Christian” came to mean a person who “doesn’t believe in the Qur'an”:

Hodzha 4: A melekyeto came to him and said, "Write this down, this, and this, and this." He couldn't write, but he learned to write. He learned to write, and the Qur'an came down. The Qur'an came down over a period of 23 years. And then those who believed in the Qur'an became Muslims, and those who don't believe in the Qur'an are now Christians. (Interview 3, Ribnovo 2005).

At first the hodzha referred to anyone who did not accept the Qur'an as an infidel. When I asked him if the "People of the Book" were infidels, too, he retracted his

388 The Qur'an; Kitab (Turkish: kitap, Arabic: kitab) - a book. 
statement and narrowed down the meaning of the term kyafir (giaour) ${ }^{389}$ to nihilists (Interview 3, Ribnovo 2005).

My respondents mostly used the word kyafir in the sense of "non-believer", a concept which does not include Christians or Jews, who are "People of the Book". However, the same respondents claim that non-Muslims cannot be saved:

Hodzha 5: It's simple, that's what it says in the two ayats ${ }^{390}$ I quoted, if you're not a Muslim, you're one of the losing ones. And that's that!

M.L.: You mean, they lose, as in, they won't go to Paradise?

H.5: Yes.

M.L.: That's terrible.

H.5: Yes, that's exactly what it says in the Qur'an. There's simply no two ways about it. (Interview 26, Satovcha 2005)

Adat Muslims take a different view, arguing that the ultimate decision about human salvation is with Allah.

In the Qur'an, Christians are described as those who "took the compact" but had "forgotten a portion" of it (5: 14), so God "stirred up among them enmity and hatred" (5: 14). The Qur'an contains more references to Jews (4: 44) (4: 46), but my respondents mostly talked about Christians in a similar way, blaming the four evangelists for departing from the original Gospel as they left out important passages and added passages of their own. This chaos is evident in the discrepancies existing between the different Gospels:

Hodzha 2: Christianity had become corrupted by people who believed they knew Christianity, but wrote other things. ... When you read the four Gospels for yourself, I mean you or anyone, you will spot discrepancies. There is no such thing in the Qur'an. (Interview 19, Ribnovo 2005)

One reason the Gospels are spurious, argued my Muslim respondents, is that they were written several decades (or, according to the mufti, 300 years) after the Ascension of Jesus (Interview 18, Ribnovo 2005). As a result, they are a mixture of truths and falsehoods, some of them heretical:

Hodzha 2: The book of Jesus Christ was lost, and nobody knows what happened to it. I mean the real book. After it was lost, four Christian men undertook to write a Bible each. But those four Bibles don't agree. One says one thing, another one denies it. Why? Because they contain additions. And Allah sent to the Prophet all those things from all the books he had sent to the

389 A godless person, an infidel, a non-Muslim.

390 (Arabic: sing. ayah, plural ay, Turkish: ayet, ayetler). 
[earlier] prophets, and brought them all together in the Qur'an. And he said, here, [this is a book] for the Muslims and for the Christians, and for the Jews, it's for everyone. (Interview 19, Ribnovo 2005)

According to the lives of prophets, the church hierarchy had selected four Gospels, turning a blind eye to their "discrepancies" and lack of orginals (al-Amili 2008, p. 477).

Bula from Ribnovo argued that the book that 'Isa had taken to heaven was actually the Qur'an, except Christians called it the Bible. In this sense, it was simply an earlier version of the Qur'an:

Bula: He is alive in the second heaven, actually, I don't know. He rose up, with the Kitab [book M.L.]. His book was Indzhil, Christians call it the Bible, but we call it the Qur'an Indzhil. (Interview 13, Ribnovo 2005)

The book of the Gospel/Injil (local Muslim variant: Indzhil, Turkish Incil), which 'Isa had always carried around and kept in his heart "since the cradle", was the only thing he was permitted to take from this world. This is why Muslims dislike the written Gospels, which they consider to be forged and corrupted versions of the heavenly original.

Translations of the Qur'an present the same danger as the texts revealed previously: once it is translated, a book is no longer sacred because the word of God has been corrupted by the word of man, and does not deserve the same kind of respect as the Qur'an in its original Arabic. Some of the Qur'an's hidden meanings are only accessible in the holy language, and may get lost in translation. This applies to all translations, because translation not only suffers from the loss of hidden meanings but also distorts the literal sense. The book remains perfect only in the original Arabic version, the "language of God" ${ }^{391}$. This is why every Muslim should know the Qur'an (or at least parts of it) in Arabic.

Hodzha 1: The Arabic language is much richer than Bulgarian. Sometimes several Arabic words have one common equivalent in Bulgarian. When a man reads a literal translation of the Qur'an, it often sounds like the same thing gets repeated several times over... but in fact it's not the same thing. You have to read between the lines, but for that you need to know more about Islam. To check the explanation of a given text if you're interested. (Interview 10, Ribnovo 2005)

From an early age, Muslims learn Arabic prayers from the Qur'an, which are used as formulas leading to salvation. The dead must recite them in the next world ${ }^{392}$, and

391 (39: 28): “an Arabic [Qur’an], wherein there is no crookedness” (42: 7): “And so We have revealed to thee an Arabic Koran, that thou mayest warn the Mother of Cities and those who dwell about it" (43: 3) “... behold, We have made it an Arabic [Qur'an]; haply you will understand. Indeed, We have made it an Arabic Qur'an that you might understand!”

392 For more on that subject see Lubanska 2005. 
they get asked which book they had served. In "Adat Islam", this belief ties in with a magical way of looking at words, i.e. the belief that uttering certain formulas can predictably cause or prevent certain outcomes ${ }^{393}$.

In this belief, two angels during the partial judgement ask the deceased person lying in his or her grave which book and which prophet they had served. The questioning takes place in the cemetery soon after the burial; the hodzha standing by the graveside feeds the correct answers to the deceased person, but it is up to Allah whether or not the dead person can hear them. Those who cannot provide the correct answers are struck by the examining angel:

Hodzha 4: When we take a dead person [to bury him or her] in the cemetery, and we place that person in the grave, two angels come and ask him which religion he had practiced - Muslim, Islamic? What did he believe? Did he believe in Allah or Muhammad? What did he believe in? If that person can answer, he does. Once an answer is given, no more questions are asked. If he doesn't answer, an angel comes. But before he can answer, the hodzha stays and tells him what to say. He tells the deceased. Because he wakes up in the grave. He wakes up. He feels around. Until he realizes he's in his grave. Then the angels come. And the hodzha reminds him of the correct answer. And if he was a believer, Allah will let him hear the right answer. But if he didn't believe in his lifetime, he's not going to believe there.

M.L.: Does the hodzha say those things quietly, or can the people hear it is well?

H.4: Well, people listen to what he says to the deceased person, to the correct answer ... They ask him what he believed in, Allah or something else, which prophet. A true Muslim will say: "My faith is Islamic, Allah created me”. But when he can’t provide the answer, an angel comes who can't see or hear. He strikes you in your grave. One strike and you become like earth [dust - M.L.]. But God creates you anew. And so you suffer your punishment until the end of the world. Bad air reaches him, bad air. Those who only believe in Allah are given a garden, the garden of $d z h e h e n-$ net. And he enjoys it until the coming of the flood. (Interview 3, Ribnovo 2005)

Unable to supply the correct answers, Christians cannot rely on a hodzha's help in their partial judgement, and so they cannot enter Paradise. Their book proves useless as a tool of salvation.

393 As already mentioned, even well-intentioned compliments must be followed in Ribnovo by the formula Mashallah (literally meaning "God's will" or "God willed it"), which is used to invoke divine protection. The formula emphasizes the speaker's good intentions and averts misfortune, a belief connected with a fear of the "evil eye". I have been told that blue-eyed women are considered the most dangerous in this respect. Children, who are particularly vulnerable to the evil eye, wear protective red thread around their wrists. 


\title{
6.3 Christianity as a Religion Based on "Misunderstanding" and "a False Cult of the Son of God"
}

\author{
Indeed, he who associates others with Allah - Allah has forbidden him Paradise!
}

(Qur'an, 5: 72)

To my respondents, the erroneous belief that 'Isa is the Son of God is one of Christianity's biggest blunders:

Sh.: That's the difference, [Allah - M.L.] "neither begets nor is he born". Nor is he like any of his creatures. That's where the differences come in. God cannot have a son. (W, M, Interview 6, Ribnovo 2005)

Hodzha 5: If God had a son he would, as a matter of principle, have to die for his son to take power. I'm talking about general rules here. Trying to find some logic in this. But how can God... I just can't wrap my head around that, how could God have a son?! (Interview 26, Satovcha 2005)

To my Muslim respondents, 'Isa is not the Son of God but the greatest prophet before Muhammad. As do Christians, Muslims believe in his virginal conception, however in the Muslim tradition he was begotten by the angel Jibra'il ${ }^{394}$ and not by the Holy Spirit. The Qur'an contains a laconic reference to this belief: "We sent unto her Our Spirit that presented himself to her a man without fault” (19: 17). My respondents explained that the conception occurred as the angel breathed on Mary's legs or touched her lower back:

Hodzha 4: And he arrived, and he pricked her in the back with his wing, and she got pregnant. That's why your people say that azreti Isa is a bastard. Meaning, he has no father and no mother, and so they call him a bastard. But he is no bastard. He was created by Allah, because the melekyetu brushed against her back, and she became pregnant. Those are Allah's mysteries, and no-one can get to the bottom of them. And when he was born, he got to believe in Allah. And he started preaching that there is one Allah, telling people to believe. (Interview 3, Ribnovo 2005)

Bula: This is what our Qur'an says about Isa peygamber. He was conceived in his mother's belly without a father. He doesn't have a father. She got pregnant by the angel Dzhibrail. He breathed on her legs, and she conceived Isa, you call him Jesus. And when he started preaching, they didn't accept that. Christians didn't accept that even though it had been foretold that they should accept [faith] from him. (W, M, Interview 13, Ribnovo 2005)

Hodzha 4 is certain that the belief in 'Isa's miraculous conception is characteristic of Islam and not shared by Christians, who consider 'Isa to be a "bastard" (an illegitimate child). His narrative about the mystery of 'Isa's conception contains elements not

394 In accordance with Allah’s will. 
present in the Gospels which can be found in lives of the prophets, such as the detail that the angel Jibra'il breathed on Maryam's dress at the level of her chest, and his breath penetrated all the way through to her womb (Al-‘amili 2008, p. 456): “'How shall I bear a son,' replied Mary, affrighted, 'since I have not known a man?' 'It is even so,' replied Gabriel. 'Did not Allah create Adam without either father or mother, merely by his word, Be thou created? Thy son shall be a sign of His omnipotence, and as His prophet, restore the backsliding sons of Israel to the path of righteousness.' When Gabriel had thus spoken, he raised with his finger Mary's robe from her bosom, and breathed upon her" (Weil 1863, p. 252-253).

The conception of 'Isa is not the first time the angel Jibra'il becomes involved in the creation of a human being: according to lives of the prophets and oral narratives of Bulgarian Muslims, the same angel had played a part in the creation of man in the beginning of the world, when God sent him to fetch a handful of dust, out of which man was later fashioned (al-Tha'labī 2002, p. 44). The angel Jibra'il in Islam performs a function similar to that attributed to the Holy Spirit in Christianity, with the important difference that angels are not divine beings, and therefore the son begotten by Jibra'il is not God.

According to my respondents, "Isa had the Gospel "written in his heart” already in his mother's womb, a belief referred to in the Qur'an which says 'Isa will "speak to men in the cradle" (3: 46; 5: 110).

Muslims believe that 'Isa worked miracles as an adult, however they do not attribute them to his divine nature. 'Isa is considered to be a less perfect prophet than Muhammad, who remains in the seventh heaven, closest to God, whereas 'Isa is only in the second heaven. According to a female respondent, this is because 'Isa transgressed in taking a needle to heaven, an act which betrayed a sinful attachment to material things:

Bula: He was meant to be taken up to a higher heaven but they found a needle on him. That's why [in the end] they kept him in the second heaven, because he had taken a needle to heaven. I mean, you shouldn't take anything to heaven on high. But there was a needle stuck right here in his coat.

\section{M.L.: Isa's coat?}

Bula: Yes. They meant to take him higher up, but they left him in the second heaven because they'd found the needle on him, [a thing of] this world. You're not supposed to take anything there!

\section{M.L.: Why did he take it?}

Bula: In order to do something. To use it for some purpose. (W, M, Interview 13, Ribnovo 2005)

'Isa carries to heaven an object connected with human labour and the hardships of this world, both of which are unknown in Paradise because they are a necessary evil 
and a consequence of the fall of the first people. As such, the needle could not enter heaven because it posed a threat to its community and harmony (Wasilewski 1989, p. 125).

Christianity's biggest errors were produced by the doctrines contained in the Gospels of Mark, Matthew, Luke and John along with the teachings of the apostle Paul, including the doctrine that 'Isa was identical to God and the cult of the Holy Trinity. The rejection of trinitarian dogma by the Muslims, who dismiss it as a human invention, is rooted in the Qur'an ${ }^{395}$. My respondents stated that Christians were in a state of shirk/idolatry, a grave sin castigated in the Qur'an on numerous occasions (3: 64, 4: 116), particularly in 5: 72-73: "They are unbelievers who say, 'God is the Messiah, Mary’s son.' For the Messiah said, 'Children of Israel, serve God, my Lord and your Lord. Verily whoso associates with God anything, God shall prohibit him entrance to Paradise, and his refuge shall be the Fire; and wrongdoers shall have no helpers.' They are unbelievers who say, 'God is the Third of Three. No god is there but One God'."

Another passage in the Qur'an, interpreted by Christians as a passage from the Gospel according to St. John $(\mathrm{J} 15,26)^{396}$, is reinterpreted in the Islamic tradition as an announcement concerning the coming of the prophet Muhammad: "And when Jesus son of Mary said, 'Children of Israel, I am indeed the Messenger of God to you, confirming the Torah that is before me, and giving good tidings of a Messenger who shall come after me, whose name shall be Ahmad"” (61: 6). Józef Bielawski, a Polish Arabist and scholar of Islam, notes that the verses reflect the etymological meaning of the name of Ahmad/Muhammad ("highly praised"), which lends itself to confusion between the Greek words parakletos ${ }^{397}$ (Paraclete), literally meaning "called to one's aid" or "advocate" ${ }^{398}$, and perikletos, which means "highly praised". According to Bielawski, this verse is an obvious echo of the Gospel of St. John (14, 16-17 and 16, 7), "And I will pray the Father, and he shall give you another Comforter [Paraclete], that he may abide with you for ever; even the Spirit of truth; whom the world cannot receive, because it seeth him not, neither knoweth him" ${ }^{399}$; "Nevertheless I tell you the truth; It is expedient for you that I go away: for if I go not away, the Comforter will not come unto you; but if I depart, I will send him unto you".

395 M. Starowieyski identifies the influence of Ebionite theology on Islam (Starowieyski 2003, p. 246).

396 "But when the Comforter [Paraclete] is come, whom I will send unto you from the Father, even the Spirit of truth, which proceedeth from the Father, he shall testify of me” (KJV, J 15, 26).

397 In J. Bielawski's Polish translation of the Qur’an, perikletos (Koran 1986, p. 937).

398 The Holy Bible (King James Version) (1611).

399 The passage continues: "but ye know him; for he dwelleth with you, and shall be in you. I will not leave you comfortless: I will come to you. Yet a little while, and the world seeth me no more; but ye see me: because I live, ye shall live also. At that day ye shall know that I am in my Father, and ye in me, and I in you" (KJV: J 14, 17-19). 
The Qur'an contains strong anti-trinitarian sentiment relating to this passage (4: 171): "People of the Book, go not beyond the bounds in your religion, and say not as to God but the truth. The Messiah, Jesus son of Mary, was only the Messenger of God, and His Word that He committed to Mary, and a Spirit from Him. So believe in God and His Messengers, and say not, 'Three.' Refrain; better is it for you. God is only One God. Glory be to Him - That He should have a son! To Him belongs all that is in the heavens and in the earth; God suffices for a guardian”.

My respondents regard the belief in the Holy Trinity as heretical and incomprehensible even to the Christians themselves:

\begin{abstract}
Hodzha 1: I've talked to many people, honestly! And they are very confused. Very! Honestly, as an outsider... when they're watching TV, they say, "What's the big deal, whether you believe in God or in Allah, it's all one and the same thing”. But it's not. Those two simply don't come together. You can't say you believe in God, and God is Jesus Christ. I believe in Allah and I say that Jesus is a prophet! Can you see the difference?! You can. It's an enormous difference. "He neither begets nor is born”. And I'm not going to start thinking, "What is his place?" "What is his image?", and so on. But he says, "He is God, born of a mother, and he walked on earth, he used to go to the toilet same as we do”, right? Jesus Christ lived for 33 years.
\end{abstract}

M.L.: It's very hard to say that God has two natures.

H.1: Exactly, it makes no sense. (Interview 6, Ribnovo 2005)

Muslims who condemn the belief in Christ's divine nature often quote the passage from the Qur'an that God "has not begotten, and has not been begotten” (112: 3):

Man H.: He did not rise from the dead. Now take the resurrection. The Qur'an says he has not risen from the dead yet.

M.L.: Why do the Christians say that he has?

H.: That's the Christian error. A human being like you or me cannot be God. Isa and Muhammad are, like you and me, human. And you know what the Qur'an says, "has not begotten, and has not been begotten”, God hasn’t. And Muhammad or Isa were born, born of mothers. What does that mean? That they are like you and me. You can’t be God, and I can't be God. (M, M, Interview 29, Ribnovo 2005)

\title{
6.3.1 The Heresies of the Apostle Paul
}

According to the local narratives, the heretical idea that 'Isa had a divine nature and was crucified comes from the activities of the apostle Paul, who intentionally spread the idea in an effort to oppose Christianity: 
Hodzha 2: He got a group of people together, and started saying that Isa was Allah. And to another group he said Isa was Allah's son, that's how it was. To another group [still] he said that Isa was a messenger, and he [the apostle Paul - M.L.] disappeared. And they all got together, say, and they began to say, "Isa is Allah's son", and others, "Isa is Allah". They started fighting with each other. Some said he was Allah, others said he was Allah's son, a third group said he was a prophet. That's how it all became tangled up in Christianity. But in fact Isa is a created man, azreti Isa and Allah are different persons. That's how barbarity became part of Christianity. (Interview 19, Ribnovo 2005)

I asked hodzha Mehmed how he knew it was the apostle Paul who introduced the Christian cult of the Holy Trinity, and he showed me a handwritten book in Ottoman Turkish entitled The Garden of Believers. Disappointingly, the title page was missing so the name of the author and the publication date are unknown.

Similar anti-Pauline elements can be found in lives of the prophets by al-'Amili: "The story of Luke is even weirder than that of Matthew and Mark, and he was a physician from Antakya (Antioch) and he didn't see the Messiah at all and he was taught the [C]hristianity from Polos (Paul) which was a fundamentalistic [J]ew against the [C]hristians and he didn't see the Messiah in his life and used to harm [C]hristians, and they said that he found out that it's of no use to harm the [C]hristians while he needed them so he preteneded to be one of them and showed that he believed in the Messiah and he claimed that he had an epileptic fit and the Messiah showed himself for him and touched him and ordered him not to harm the christians, and since that time he believed in him and the Messiah sent him to spread his gospel, and talking about him would be long and bad to hear, and he legalized for them to eat the carrion and the wine drinking and that he knew that faith only is enough to servive without doing anything, and the writing of the gospel of Luke was after that Mark wrote his own and that was after the death of Peter and Paul” (Al-‘amili 2008, p. 477).

Anti-Pauline sentiment is also found in propaganda pieces popular in some Islamic circles, such as the Gospel of Barnabas ${ }^{400}$, or in more recent books and articles posted on the Internet. One was pointed out to me by Ayshe and Izmet, a married couple of teachers from Satovcha who are Salafi Muslims. When asked about St. Paul, they recommended to me the second edition of Bibliyata, Koranŭt i naukata, a book by Maurice Bucaille (2004) available in the local bookshop ${ }^{401}$. The book contains a separate chapter devoted to the apostle Paul, Historical Reminder: Judeochristianity

400 Starowieyski argues that this pseudoapocryphal became an element of Islamic propaganda to attract the attention of Christian scholars of Islam, both theoretically (as a demonstration of the connections between Christianity and Islam) and practically (to counteract its propaganda effect) (Starowieyski 2003a, p. 247).

401 The book was published by Bulgaria‘s Main Muftiate in 2004 ( $2^{\text {nd }}$ edition), and is available in English as Maurice Bucaille, The Bible, the Qur'ān and Science: The Holy Scriptures Examined in the Light of Modern Knowledge, translated by Alastair D. Pannell and Maurice Bucaille, Islamic Call Society, Tripoli, 1976. 
and St. Paul, in which Paul is portrayed as the founder of a new faction within Christianity (existing today), locked in a struggle with the orthodox Christianity of the apostle James which it ultimately supplanted, as suggested by the fact that the Council of Jerusalem in 49 A.D. exempted Christians from "circumcision and other Jewish observances” (Bucaille 2004, p. 76).

A religious education teacher, Izmet from Satovcha, said:

Izmet: [St. Paul] introduces new things, producing a contradiction between what we might call the two schools, orthodox Christianity and the new elements Paul introduced into Christianity. But I would need to find out more about these things to discuss the major points. A man ought to know about those things. (Interview 26, Satovcha 2005)

The Pauline version of Christianity abolishes the observances which the human souls in Paradise had vowed to keep, and which later became reaffirmed in the Qur'an.

The accusation of religious negligence directed at neighbours of different faith implies that they cannot be saved, a fact deliberately glossed over in silence by both religious groups. The Muslims believe that 'Isa taught those ritual observances, and, by abolishing them, Paul discredited Christianity in the eyes of Islam (and Judaism) by turning it into a completely different religion where faith and charity are pitched against Law.

Anti-Pauline ideas are not limited to "Adat Islam" or Muslim propaganda literature aimed at Salafi Muslims. The problem seems to touch on the heart of the difference between the two religions, and currently receives attention from different social groups. The questions it poses can be treated as a rejuvenating influence in Christian religious tradition, provoking reflection on what an alternative Christianity might look like had it been modelled along the lines of the teachings of apostle James.

\subsubsection{Narratives Questioning the Christian Cult of the Cross}

The cult of the cross is another example of Christian idolatry, introduced by Satan in the times of the prophet Nuh, who persuaded people to put crosses on the graves of dead prophets, ultimately leading to the emergence of the Christian cult of the cross:

Hodzha 1: Those Christian crosses are a lie. This goes back to Nuh, that's where the lie began. There had been five people before him, before Nuh. And they were exact [meaning: orthodox - M.L.] before God, they believed right. And one by one, one by one they died. Nehub, Nehud, Nesra [lists the names of the prophets - M.L.]. I would have to look that up in a book. And they believed well in Allah, and [they believed] in that religion, in those books. One by one they were lost, they died. And people wondered what to do. Because there were no leaders, no one to replace them. And Satan appeared among them in human form: "Let me tell you what you should do to make things easier!" ... He came to deceive them, to have them put crosses on the graves of those five men. "If you respect them so much go there and pray to them", and it is written that floods came and all those things were lost. But Satan, who is powerful, found a way. 
He found those things [buried] in the sand, and reintroduced them, he gave them to some people and invited them to believe. Azreti Isa did not permit that, absolutely not. But people believed, they put them on churches and so on. (Interview 19, Ribnovo 2005)

This mistrust of crosses is connected with the iconoclastic sentiment of Islamic religious culture, and with its rejection of Christ's crucifixion. My Muslim respondents told me that Christ did not die on the cross ${ }^{402}$, but a lookalike was executed instead, possibly Judas or another associate whose face God changed to look like 'Isa.

Bula: It wasn't Jesus who got crucified, it was his friend Judas. Allah gave his face to Judas. He was caught. (W, M, Interview 13, Ribnovo 2005)

Sh.: They make the sign of the cross because Jesus was apparently crucified, they're even showing this film in the cinemas ${ }^{403}$, but he wasn't crucified, and that's why they make the sign of the cross today. They make the sign of the cross. (W, M, Interview 13, Ribnovo 2005)

According to hodzha Mehmed, the fact that Judas was crucified instead of 'Isa is confirmed by the fact that two mothers were looking for their lost sons at time: the mother of 'Isa and the mother of Judas:

Hodzha 1: They caught him and crucified him. They did what they had to do. All right, but then you get two mothers looking for their sons. Isa's mother and that other one's mother. When they lost their way...

M.L.: They lost what?

Woman Sh.: One of them disappeared, right? Angels raised him up to heaven.

M.L.: And the other one was a lookalike.

W.Sh.: The other one was a lookalike, so it stands to reason, since both are gone, that means angels had taken Isa up to heaven.

H.1: And then they crucified their friend, and made a Tomb of God, or whatever they call it, it's total baloney, but that's how it is. That's how they were duped. (Muslims, Interview 19, Ribnovo 2005)

According to Marek Starowieyski, the belief that Jesus was replaced on the cross by a man who looked like him is a docetic idea: people assumed that Jesus had been

402 Cf. Surah 4: 157: “...and for their saying, We slew the Messiah, Jesus son of Mary, the Messenger of God' - yet they did not slay him, neither crucified him, only a likeness of that was shown to them. Those who are at variance concerning him surely are in doubt regarding him; they have no knowledge of him, except the following of surmise; and they slew him not of a certainty - no indeed”.

403 Probably referring to The Passion of the Christ directed by Mel Gibson (2004). 
crucified but what they actually saw was an apparition or possibly another person crucified instead of Jesus: Simon of Cyrene, Jesus ben Pandera (misidentified by Judas, one of the Twelve) or Judas himself (cf. Starowieyski 2003b, p. 176).

This belief can also be found in lives of the prophets ${ }^{404}$ or in the Gospel of Barnabas (The Gospel... 1907), a pseudepigraphical work composed by Muslims in Spain ${ }^{405}$. The narrator claims to be a disciple of Jesus ${ }^{406}$, one of the few people (including the mother of Jesus, John and his brother James) who remained faithful to his teachings and did not believe in his death on the cross (The Gospel... 1907). According to the Gospel of Barnabas, Jesus hid from Judas and the soldiers in a house together with the other apostles, and he was raised to heaven by angels on God's command (a detail also present in the narratives of my respondents). Judas was made to resemble Jesus, leading to his arrest and crucifixion. Again, this detail is also found in lives of the prophets (Weil 1863, p. 259).

In addition to the erroneous belief in Christ's crucifixion, the Christian cult of the cross also involves a misinterpretation of a gesture Jesus made just before his assumption ${ }^{407}$ when he stretched out his arms to complain to God that they would not squeeze through the opening God made for him in heaven. Seeing his outstretched arms, the apostles assumed it was part of his prayer, an expression of the cult of the cross ${ }^{408}$ :

Hodzha 4: Icons, icons are strictly prohibited, people mustn't believe in them. The cross, that Jesus Christ they carry around in churches, that's absolutely forbidden in the w Qur'an. When you pray to a cross there is nothing the cross can do to help you. If you pray to Allah he will help you. But when you look at a cross, you're praying to that cross. You're praying to Jesus Christ. Jesus Christ is human, like us! And when they wanted to crucify him and kill him, destroy him, God took him up to heaven. God told him, "Go on, Isa", he said, "Rise up to heaven, and be freed from your people who are out to kill you". He looked up, and he saw a little opening up there. And he says, "But 'rabbi' [Arabic: rabbi - my Lord/my God!] my head can squeeze through. But this arm, and this, how can my arms squeeze through?!”. And the people who were with him, when they saw that, they started making the sign of the cross, like he did.

404 Cf. also Weil 1863, p. 263, a passage which talks about 'Isa giving up the ghost and dying for three hours, after which time the angel Jibra'il raised him to heaven through an opening in heaven.

$405 \mathrm{Fr}$. M. Starowieyski points to recent research to suggest that the book presents the life of Jesus in keeping with the teachings of Islam because it was written by Spanish Moriscos (crypto-Arabs) (Starowieyski 2003, p. 246-247). Much earlier, a book by P. Beskow (1979) speculated that the work might have been written between the 14th and the 16th centuries by a former Italian Christian who converted to Islam (Beskow 2005, p. 31-37).

406 The only surviving version of the work was written between 1300 and 1349. It plays an important role in Islam as a propaganda piece (cf. Starowieyski 2003, p. 246-247).

407 I use the word "assumption" rather than the Christian concept of "ascension" because in the Islamic tradition 'Isa was raised up to heaven according to Allah's will rather than by his own power. 408 The local Muslim interpretations are silent about any connection between the sign of the cross and the Holy Trinity. 
M.L.: So, he gestured to show he couldn't squeeze through? [The respondent makes the sign of the cross when quoting the words of Jesus - M.L.]

H.4: "My head can squeeze through, but this arm, and this, how can they squeeze through?" Allah commanded him and gave him strength. And he rose up to heaven. And he is alive now.

M.L.: Meaning, you believe that Christ was taken up to heaven?

H.4: That's what we believe. And one day he will come come back to earth. When the end comes, he will come down. (Interview 3, Ribnovo 2005)

Hodzha 4: And from that moment, Christians have been making the sign of the cross. We believe in one Allah and nobody else. There are no crosses on our mosques. Just look. There are no photographs there, nothing. In churches there are crosses and photographs. There's Mary and her children. Those are all lies. (Interview 3, Ribnovo 2005)

To my respondents, the idea of kenosis or the self-humbling of God, who became human to save humankind through his death on the cross, seems to be the most incomprehensible element in Christianity. They view the famous patristic idea that "God became man so that man can become God" as a heretical notion which amounts to rejecting Islam. Accordingly, this central element of Christian faith is vehemently rejected and depreciated.

Sh.: How could the Highest expose his prophet to so this kind of torture, and take him away afterwards?! If anything, Why not take him away beforehand? What's the point of making him suffer?! (W, M, Interview 10, Ribnovo 2005)

Seyyed H. Nasr points out the scale of this problem: "the most difficult aspect of Christianity for a Muslim to understand is the significance of the cross. Generally, a Muslim cannot understand why a Christian bows before the cross, carries it and in moments of distress makes the sign of the cross. From the other side Christians face the same difficulty vis-à-vis this 'magical' aspect of the Qur'an which Muslims carry with them and recite to gain support and protection” (Nasr 2000, p. 41).

In the Rhodopes, this depreciation of the cross is probably caused not only by Islamic theology, but also stems partly from the gnostic legacy of Bogomilism, of which the Pomaks are sometimes supposed to be continuators ${ }^{409}$ since, according to one theory, they are descended from Bulgarian neo-Manicheans. Galina Lozanova noted a belief among the Muslim population in the Central Rhodopes, according to which Jesus ('Isa) himself will put an end to the cult of the cross in the final days:

Isa will destroy the cross and kill the pig. This, too, is a Muslim belief. (Hamid Imamski, cited in: Lozanova 2000, p. 69, translated from Bulgarian)

409 Related to the concepts of Pomak ethnogenesis discussed in Chapter 1. 
According to Muslim legend, this spectacular gesture was announced by Jesus when he was taken up to heaven and stood before his mother, Mary. He said, "at the approach of the last day, I shall be sent again upon the earth, when I shall slay the false prophet Dadjal [Dajjal ${ }^{410}$ and the wild boar (both of which cause similar distress in the earth), and such a state of peace and unity shall ensue, that the lamb and the hyena shall feed like brothers beside each other. I shall then burn the Gospel, which has been falsified by ungodly priests, and the crosses which they have worshiped as gods, and subject the whole earth to the doctrines of Mohammed who shall be sent in later times” (Weil 1863, p. 259).

Hodzha 1: I mean, Isa ascended to heaven and we're awaiting his return, that's what our books say. There will be ten omens, and one of them is, what's the word, resurrection. There will be a flood. This is one of the ten omens. And then he will return to Syria, and thousands will be waiting for him. (Interview 19, Ribnovo 2005)

As with the beliefs concerning Adam and Hawwa, my respondents' beliefs about Jesus are meant to validate Islam as the religion God had always intended for mankind. In this view, Adam, Hawwa and Jesus are figures who had been systematically preparing mankind for the coming of Islam. In the legend of Adam and Hawwa, Islam is prefigured by their actions (ablutions, the covering of the body) and by the narrative of the promise the souls had made in Paradise. In Muslim narratives, Jesus paved to the way for Muhammad, just as the Christian narrative holds that John the Baptist paved the way for Jesus. However, it will be Jesus, not Muhammad, who will play an important role in the time of the Apocalypse by defeating Dajjal and lending support to Muslims:

Bula: It is written, "When he comes down from heaven, he will let them know that they believed in God, they believed in Jesus”. But he wasn't God, he was a prophet. And he is alive in heaven. He will come down, and there will be signs, before the flood comes he will come down here, alive. He will get married ..., He's not married, he will have two children, and he will be praying somewhere in the mountains, and his soul will be taken away from him. He will fight here with Dajjal, the infidel, and he will win. And he will point the way to the Muslims as our peygamber. But there will be no more peygambers, prophets. Ours was the last. It is written in the Kitab that ours was the last, there are no more prophets. (Interview 13, Ribnovo 2005)

Practically each of Isa's actions after coming down to earth will expose Christianity as a false religion, from his secular lifestyle (marriage, children) ${ }^{411}$ to his victory over Dajjal and his support of Muslims.

410 The Antichrist, one of the signs of the end in the Islamic tradition.

411 This brings to mind Martin Scorsese's The Last Temptation of Christ (1988), which suggests that such a decision would amount to abandoning the act of redemption in the Christian sense. 


\subsubsection{The Pernicious Reforms of Pope Gregory I}

To my respondents, Christianity is a religion based on a false understanding of the sacred, bearing the original taint of the sin of shirk and stemming from a long series of misunderstandings, which to my respondents are foundational to Christianity. The major foundational events of Christian history are reinterpreted as reprehensible incidents in which Christians strayed permanently from the path of salvation. Christian sacred history becomes mere heresy, a belief my respondents openly incorporated into biblical narratives.

There is also another way of reinterpreting Christianity as a false religion, which focuses on the reforms of "Pope Gregory". According to Hodzha 6, Christianity was a legitimate religion until "Pope Gregory" (presumably Pope Gregory I) pushed through a series of reforms which dealt a lethal blow to Christianity by merging it with paganism, leading to persecutions of true Christians:

Hodzha 6: That's why Christians used to be true believers. They used to be true believers. But when Pope Gregory came, he started persecuting orthodox Christians and killing them.

M.L.: Why?

H.6: He wanted money, he wanted authority, he wanted power, but he didn't know..., I mean, he forgot the fact that he was mortal. This was a time of big problems for mankind.

M.L.: Pope Gregory?

H.6: Pope Gregory.

M.L.: Why did he expel Christians?

H.6: Because they prayed to God, not to idols. Not to shamanism, like that Ilinden [St. Elijah's Day- M.L.] yesterday, not to shamanism.

M.L.: Is Ilinden shamanism?

H.6: Ilinden is a shamanistic holiday, a pagan holiday. So is Sveti Georgi. Those are made-up heroes, from the pagan times, do you understand? (Interview 30, Satovcha 2005)

Notably, the respondent does not distinguish between Roman Catholicism and Orthodox Christianity, and uses the Orthodox celebrations of St. Elijah's Day or St. George's Day to illustrate the supposedly shamanistic/pagan consequences of Pope Gregory I's reforms. Cleansed of the pagan “additions” introduced by Pope Gregory I, the hodzha believes that Christianity would be essentially identical to Islam:

Hodzha 6: Pope Gregory mixes it all up. Shamanistic holidays and Christian holidays. Do you understand? 
M.L.: You mean, he was the one who made that mess?

H.6: He made all that mess, and the problem is still unsolved.

M.L.: So, you mean, pure Christian faith is like Muslim faith?

H.6: Yes, both are one thing.

M.L.: Does pure Christian faith even exist any more, or is it gone because of Pope Gregory?

H.6: It's gone. That's why God... that's why... I mean, Jesus says... I think it's Psalm 35 in the Bible where he says: "And a second Messiah will come after me, and you must follow him". That's what it says in the Bible, in Psalm 35, in the chapter on "Judaism”. Read verses 25 to 40, something like that... I'm not sure, maybe it was Psalm 33. It speaks of Muhammad. It says: a new messiah will come after me, and you must all follow him. (Interview 30, Satovcha 2005)

The vague and unsubstantiated reference suggests that the hodzha is not very familiar with the Bible, and is probably referring to a passage from the Gospel of St. John about the coming of the Paraclete $(15,25)$, reinterpreted in Islam as a foretelling of the coming of Muhammad (see above).

In terms of religious concerns, Muslims in the Western Rhodopes are strongly preoccupied with validating Islam as a religion superior to Christianity. At the same time, they treat religion as the most important criterion distinguishing them from Bulgarians. The local Muslims seem to think of communities through the lens of Ottoman millets ${ }^{412}$ rather than in ethnic or national terms.

Muslim narratives (whether in Adat or Salafi models) regard the foundational events of Christian sacred history in terms of misunderstanding and misinterpretation, portraying them as human inventions unrelated to the will of the monotheistic God. In this vision, Christianity not only holds no attraction for Muslims but also, given its polytheistic and idolatrous elements such as the trinitarian creed or its cult of the Son of God, is seen as downright dangerous. This suggests an anti-syncretic attitude, even if some of my respondents (those who embrace the Adat model) accept that some good Christians may be saved (cf. stories of good Christians being taken by camels to Muslim graves, and the bodies of bad Muslims being found in Christian graves).

The next chapter looks at the attitudes of the local Christians towards the Bulgarian-speaking Muslims.

412 A system of limited self-governance for confessional communities in the Ottoman Empire, abolished after the liberation of Bulgaria at the turn of the 19th century. 